\title{
Roots radical - \\ Place, power and practice in punk entrepreneurship
}

Sarah Louise Drakopoulou Dodd

The significance continues to grow of scholarship that embraces critical and contextualized entrepreneurship, seeking rich explorations of diverse entrepreneurship contexts. Following these influences, this study explores the potentialized context of punk entrepreneurship. The Punk Rock band Rancid has a 20-year history of successfully creating independent musical and related creative enterprises from the margins of the music industry. The study draws on artefacts, interviews and videos created by and around Rancid to identify and analyse this example of marginal, alternative entrepreneurship. A three-part analytic frame was applied to analysing these artefacts. Place is critical to Rancid's enterprise, grounding the band socially, culturally, geographically and politically. Practice also plays an important role with Rancid's activities encompassing labour, making music, movement and human interactions. The third, and most prevalent, dimension of alterity is that of power which includes data related to dominance, subordination, exclusion, control and liberation. Rancid's entrepreneurial story is depicted as cycles, not just a linear journey, but following more complicated paths - from periphery to centre, and back again; returning to roots, whilst trying to move forwards too; grounded in tradition but also radically focused on dramatic change. Paradox, hybridized practices, and the significance of marginal place as a rich resource also emerged from the study.

Keywords: entrepreneurship; social construction; punk rock; paradox; marginality; periphery

Special thanks are due to all the punks and skins who have engaged with my reading of the Rancid story, and given me so much support and feedback along the way, especially Rancid's drummer, Branden Steineckert, Jesse from Machete Manufacturing, Kostis, Tassos (Rancid Punx Athens Crew) and Panayiotis.

\section{Introduction}

A wider framing of the entrepreneurial process beyond the conventional economic, managerial and normative frame has long been called for (Chandler and Lyon 2001; Coviello and Jones 2004; Gartner 2004, 2010a, 2, 2010b; Grant and Perren 2002; Jones and Spicer 2005, 236; Ogbor 2000, 622; Steyaert and Hjorth 2003; Steyaert and Katz 2004, 189). This is likely to draw on more creative, experimental, contextualized, critical studies, richly grounded in qualitative data (Cope 2005; Down 2010; Gartner 2010b; Steyaert 2005, 7). Indeed, the significance continues to grow of scholarship that embraces what is sometimes called the 'European tradition' of critical and contextualized entrepreneurship:

This, I think, is a commonality of a European sense,

That context matters, and makes the difference. (Gartner 2008, 364; see also Down 2013, 1; Tedmanson et al. 2012, pace Davidsson 2013) 
Entrepreneurship research, in this view, can and should strive to be entrepreneurial, to embrace imagination, diversity, exploration, openness and engagement, to become 'a more creative and curious entrepreneurship studies' (Steyaert, Hjorth, and Gartner 2011, 4; see also Steyaert 2011, 77). There is 'a potentialized context, where we can actualize this entrepreneurship, those entrepreneurs that have hitherto been missing' (Hjorth and Steyaert 2010, 228). An established and growing scholarly demand, then, seeks for grounded explorations of diverse entrepreneurship contexts, agents and processes, to mitigate a perceived tendency for narrowness. ${ }^{1}$ Taking such potentialized context seriously has multiple implications, for both what we study, and how we study it:

\begin{abstract}
Researching entrepreneurship in its contexts is not only about recognizing the complexity and diversity of the phenomenon and its contexts for theory and methodology as such, but it is also about listening to each other and recognizing contributions outside the mainstream debate. (Welter 2011, 178).
\end{abstract}

Simply put, a research gap has been identified that seeks the delineation and analysis of alternative enactments of entrepreneurship, and the 'missing' entrepreneur, paying special attention to social situatedness. Beyond exploring such meaning-frames as of merit in their own right, however, such context-specific 'missing' entrepreneurship is also anticipated to contribute to our wider extant theorizing, providing a contrast to shed new light on the 'mainstream'.

Bengt Johannisson can fairly be described as a founding father of this highly contextalized and engaged approach to entrepreneurship scholarship, highlighting 'the social situatedness of entrepreneurial activity' (Fletcher 2011, 68; Steyaert 2011; Steyaert and Landstro"m 2011; Steyaert, Hjorth, and Gartner 2011). Placing potentialized context at the heart of our scholarship, like Johannisson, brings into the foreground a number of related issues, perhaps most especially those of place, of power and of practice. Place matters, as the social site of entrepreneurship, the relational and material geography that shapes practice, and is shaped by it in turn. Power matters, as we work to engage with minority voices from beyond the mainstream, with the missing entrepreneurs, and as we confront political rhetorics of the entrepreneur. Potential, after all, means to have possibility, capability or power. Practice matters, as we consider the everyday contextualized lives of people doing entrepreneurship: connecting, cocreating, working and playing. The aim of this paper is to use the three-part analytic frame of place, power and practice to explore a specific example of 'missing' 
entrepreneurship. These three core elements of situated context - and especially of marginal situated context - offer an analytic lens through which data can be interrogated, so as to see what actors do (practice), where they do it, and with whom (place) and how their possible actions and relationships are structurally influenced, facilitated or impeded (power). It is hoped thereby to contribute to our theoretical understanding of these three important and interlinked aspects of entrepreneurship. In addition, a deeper and richer appreciation of non-mainstream entrepreneurship is sought, most especially in relation to the places, practices and power/lessness of the 'missing' entrepreneur.

To achieve these objectives, this study explores entrepreneurial place, power and practice through the lens of an alternative countercultural meaning-frame of enterprise, as enacted by punk rock. Punk rock is a heterogeneous 35-year old radical movement which combines cultural production and independent economic action. As Tucker writes, 'punk is, in its own way, a site of dissident knowledges and practices that stand in resistance to the culture industry and dominant order' (Tucker 2012, 211). In the discussion of place, power and practice which follows, I will explain further why punk rock is such an appropriate study site for empirical consideration of these three phenomena.

The punk rock band Rancid has been chosen as the focus of this study because they have survived for more than $\mathbf{2 0}$ years on the margins of the mainstream music industry. They have also launched a number of innovative entrepreneurial projects, which have experienced considerable commercial and economic success as well as artistic plaudits. My objective is to document and analyse this missed context of entrepreneurship, using the frame of place, power and practice. Engaging with such marginal and unusual contexts can be expected to shed new light on received wisdoms, whilst also generating fresh insights into entrepreneurship. The project is open and experimental, exploring an unstudied and perhaps extreme entrepreneurial context, in a spirit of curiosity as to what we can learn from such a process. As Ca'las, Smircich, and Bourne $(2009,553)$ put it: 'traditional perspectives on entrepreneurship aim to reproduce a specific economic system - market capitalism - and assume it will benefit all'. This study challenges such traditions, by giving voice to an alternative form of entrepreneurship, which explicitly confronts the assumptions and practices of market capitalism, as we shall see.

The manuscript takes the following path. First, I will discuss in a little more detail the three contextual elements of place, power and practice, which provide the analytic frame of the study. Next, I will briefly present the do-it-yourself (DIY) ethic of punk rock, the local context within which Rancid emerged, and the band's history, before explaining the methodology deployed to study them. Then, the study's findings are shared and analysed, before discussion of their wider significance. Finally, a concluding section will draw together the study's threads, consider directions for future research and acknowledge the inevitable limitations of the work. 


\section{Place, power and practice}

\subsection{Place}

A key legacy of Bengt Johannisson to entrepreneurship is his career-long insistence that place - socio-geographical settings of entrepreneurship - must be at the very heart of what we do. 'demonstrating how the organising context becomes the generative device of a range of independent and dependent variables for producing (different) structural, strategic, behavioural and resource combinations' (Fletcher 2011, 68). Such a view implies recognition that places are complex sites of enculturated social engagement, where creative collective organizing (or 'entrepreneuring') is enacted through networks of relationships:

Places are not simply sites of production and consumption, but areas of meaningful social life where people live and learn; they are locations of socialization and cultural acquisition. Places are made up of a complex system of social relations and material objects. Place creates a distinct culture, has meaning and both has and creates identities. (Johnstone and Lionais 2004, 219) ${ }^{2}$

Indeed, Banks has found that 'cultural entrepreneurs, rather than being "despatialized" and "desocialized" (McRobbie 2002), appeared to be highly attuned to the social milieu into which they were embedded' $(2006,463)$. He argues that it is this social and historical grounding which enhanced the ethical and anti-market communitarian cultural logic, 'an embedded moral economy', that he identified in his study of creative industry entrepreneurs in Manchester $(2006,464)$. Place, shaped the alternative normative and entrepreneurial meaning-frame dramatically (2006, 464-465). Other scholars have argued that place is especially important to punk rock. ${ }^{3}$ The (punk rock) place where the study unfolds is a marginal locus, a peripheral socio-economic setting beyond the mainstream world of the music industry, a locus of scant resources and of meaning systems which co-create discourses of alterity, as we shall see shortly. It is thus an especially apposite context in which to study place, understood here as 'a social evaluation of location based on meaning' (Johnstone and Lionais 2004, 218).

There is a strong argument for exploring the social places beyond the mainstream, not least since 'entrepreneurship means literally an-in-between' and 'the border is the only place where one can be, in the middle, in the transitional zone, in a strange home territory' (Steyaert 2005). Steyeart draws on Deleuze's concept of the middle to argue for entrepreneurship scholarship as a rhizome, suggesting we 'practice principles of connection and heterogeneity, principles of multiplicity, principles of rupture, shifting directions and lines of flight, principles of carthography and multiple entrances, and, as said, the principle of the middle'. This is surely as true of the practice of entrepreneurship, as of our work as its scholars. That is, a fundamental topos of entrepreneurship is the frontier zone, the middle, the dynamic place between institutions, where heterogeneity and connections can arise in some freedom from institutional constraints. Rising to Steyeart's plea that we address dominant ideologies of entrepreneurship by multiplying 
our scholarship - pursuing 'a polyphonic richness of approaches' - then entails giving voice to those beyond the ideological borders. To address the dominant entrepreneurial myth, we must seek out and study those whose discourse, praxis, relational matrices and cultural logics are effectuated, strategically, in 'the middle'.

\subsection{Power}

As Steyaert and Katz have pointed out, entrepreneurial contexts 'are political spaces that can be constituted through a variety of discourses overcoming the sole economic definition of the societal contexts that impacts and is impacted by entrepreneurship. A geography of entrepreneurship is always a geopolitics' $(2004,180)$. All contexts, that is to say, are partially constructed through the deployment of power, and by the structures of powerfulness and powerlessness that this enacts. This has been well discussed by organization studies scholars exploring institutional entrepreneurship. There is increasing recognition that (institutional) entrepreneurship is an agonic political process, where the dominant incumbents tend to deploy both power and resources to maintain the status quo, whilst newcomers, and other subordinate institutional actors, struggle strategically to induce novelty whilst simultaneously requiring field legitimation to achieve their aims (Clemens and Cook 1999; Garud, Jain, and Kumaraswamy 2002; Levy and Scully 2007; Lounsbury and Ventresca 2003). Levy and Scully have invoked Gramsci's Modern Prince to highlight the significance of power and strategy to institutional entrepreneurship. Strategy, in this view, incorporates not only discursive moves, but also material, relational and organizational elements (Levy and Scully 2007, 11). Similarly Bourdieu's field is a local relational space, shaped by the dynamics of contests between the dominant, and the dominated, and by the relative positions of each (Golsorkhi et al. 2009, 782; De Clercq and Voronov 2009a, 801). Each has its own logic, its own tussles for structural position, for 'political' power, and for the specific capitals valued by the field (Friedland 2009, 888; Bourdieu and Wacquant 1992, 97-101). Dominant and subordinate field members, incumbents and newcomers alike, are embedded in these relatively autonomous fields, and their actions shaped towards its norms and structures (De Clercq and Voronov 2009a, 805; Bourdieu 2000). Power, in these terms, is inherently relational also, embedded and enacted in field systems and structures, and challenging (for) these, strategically. For institutional entrepreneurs, 'strategy can be a generative form of power', with their agentic interventions acting on indeterminacy and opportunity to struggle against the status quo (Levy and Scully 2007, 13).

A key plea from 'New European' entrepreneurship scholars has been that we pay greater attention to marginal voices, to the 'missing entrepreneurs', to those without access to power. Specifically, Gartner $(2013,5)$ proposes that we engage more fully and openly with the 'other' in entrepreneurship, which includes marginal, non-hegemonic, people, communities and discourse (Watson 2013; Imas, Wilson, and Weston 2012; de 
Sa' Mello da Costa and Luiz Alex Silva Saraiva 2012). Johnstone and Lionais argue that "in locations where capitalistic relations are less robust, such as depleted communities, the entrepreneurial process may adapt and manifest itself differently $(2004,218)$. Places without (capital) power will demand, provoke and create novel entrepreneurial responses to this condition" (Johnstone and Lionais 2004). They show that depleted communities' powerlessness is expressed in their lack of access to venture capital, labour skills and support institutions. Responses to such geopolitics can include, as the Johnstone and Lionais' examples show, community business entrepreneurship using innovative deployment of sound business ideas, networking beyond the depleted community, and a clearly articulated and enacted vision. Wealth is construed as benefits for the wider community, rather than individual profit (Johnstone and Lionais 2004, 219-226). As this example illustrates, unusual contexts generate new lenses for re-storying entrepreneurship, which move consideration away from the typical white middle-class setting, with its endowment of social, cultural, human and economic capital (Rehn and Sko“Id 2005; Sko“ld and Rehn 2007, 53). By selecting a research context which is characterized by its marginality, it is hoped to throw into sharp relief new examples of entrepreneurship which do not - cannot-draw on the resources at the disposal of more powerful societal groups.

Entrepreneurship is political - has to do with power - in (at least) one other important sense, too. As Rehn and Taalas have pointed out the state of "'being entrepreneurial" is in modern political and economical discourse shorthand for efficiency, development, energetic communities and similar moral goods' $(2004,236)$. This rhetoric has, as they show (236-239), infected and restricted entrepreneurship scholarship, so that looking outside market capitalism for examples of entrepreneurship is almost definitionally prohibited. Levy and Scully warn that the hagiography of the entrepreneur and its discursive, emotional power as a myth can serve to stimulate the reproduction of dominant socio-economic power structures. Attracting agents and resources to its symbols of idealized, individualistic, passion, discourse of the entrepreneur forms a nexus that serves to continually re-enact and renew hegemonic power structures (Levy and Scully 2007, 16-17; Jones and Spicer 2005). Entrepreneurship, then, is 'a narrative structure to the fantasy that coordinates desire' (Jones and Spicer 2005, 236), and entrepreneurship scholarship has often been complicit in reifying and mythologizing this discourse (Ogbor 2000, 605). By turning to hear the voices of the voiceless, this political rhetoric of our field is also challenged, and its hegemony questioned. Again, punk rock suggests itself as an excellent research site, since it is inherently marginal and resourcepoor, as well as a being genre whose discourse challenges the socio-economic status quo. 


\subsection{Practice}

De Clercq and Voronov point out that

recent social constructivist writing on entrepreneurship parallels the practice perspective by pointing out that entrepreneurship is not so much about the stereotypical, heroic posture of elite groups of actors but the everyday activities that take place through sociocultural processes in local neighbourhoods and communities. (2009a, 397)

Power and place, are enacted through the patterned actions of embedded agents, including entrepreneurs. Bourdieu's concepts of habitus and practice have been argued to provide a tractable analytic lens for making sense of such modus operandi (and vivendi) in a manner consistent with the 'European Tradition' of contextualized and critical entrepreneurship research (Anderson, Dodd, and Jack 2010; De Clercq and Voronov 2009a, 2009b).

Entrepreneurial (inter-) actions are articulated within relationships and social structures: 'both context and act constitute each other reciprocally' (Rehn and Taalas 2004, 237). Writing of networking practices, Anderson, Dodd, and Jack (2010) describe these practices as "the "getting by and getting on" actions which entrepreneurs engage in as they grow their ventures'. In Bourdieusian terms, these practices are an expression of habitus, which itself is the shared and evolving 'rules of the game, its spirit and logic... the generative grammar of a field, the cognitive assumptions which shape behaviours, and give meaning to them' (Drakopoulou Dodd, forthcoming) Habitus is 'an active residue, of past actions that function in the present to shape perceptions and mould practices' (Anderson, Dodd, and Jack 2010). Thus, practices express and enact habitus, the cocreated social place that codifies, inter alia, power.

Similarly, strong arguments have also been made of late proposing that we broaden our view of entrepreneurship to consider the prosaic, the mundane, the everyday entrepreneuring of creative, imaginative, interactive organizing (Johannisson 2011, 136; Johannisson and Olaison 2007, 58-59). This requires us to recognize that 'entrepreneurship is a matter of everyday activities rather than actions of elitist groups of entrepreneurs' (Steyaert and Katz 2004, 180). Instead of focusing on the pseudorational readings of entrepreneurial planning and staged action (Johannisson 2011, 136), it is past time for us to consider also 'mundane movements undertaken by regular people in an economic space of the everyday' (Rehn and Taalas 2004, 249). Focusing beyond the mainstream, into the marginal world of punk rock, represents just such a step.

To engage more fully with context, to uncover diverse discourses and practices of entrepreneurship, we also need to consider a wider range of entrepreneurial practices, with the narrow boundaries of private new firm start-ups, and to consider elements of context which interact with these, include political, aesthetic and community practices. To move beyond a narrow (market) economic comprehension of entrepreneurship (Rehn and Taalas 2004), we need to study practices whose main purpose may well not be simply economic, but rather to do with creation, novelty and the organization of resources for other purposes. These practices are of interest in their own right, as entrepreneurial 
action, but also can be expected to lay bare alternative discourses of entrepreneurship, to challenge those which have become overly dominant and unquestioned. To borrow a little poetry from Bill Gartner:

The heart of environment is embedded in values and culture,

And a society's values are voiced in its music and literature. (Gartner 2008, 364)

We also do ourselves and our scholarship a grave injustice if we fail to acknowledge that we too are emotionally engaged, socially embedded actors, creatively organizing resources in not always rational ways. A greater courage and openness is needed in not just what we do, but also how we justify these scholarly processes in our writing:

if entrepreneurship studies needed to be based on entrepreneurial practice itself, that pioneering practice would require a form of curiosity, radicality and confrontation that allows one to question the taken-for-granted assumptions of knowing and the usual ways of proceeding. (Steyaert and Katz 2004, 188)

I have tried hard here to explicitly set out here the contextualized conceptual approach - drawing on place, power and practice - which informs my work, and shown my hand clearly as a co-producer of knowledge. The colleagues whose work I have briefly highlighted here are those who have shaped the way I 'read' entrepreneurial contexts, and it would be disingenuous not to articulate this perspective. I acknowledge fully my passionate engagement with Rancid's music, and my great affection for their story, as well as the 20 years of studying, reading, writing and thinking about entrepreneurship which I bring to this endeavour. I hope that in selecting such an atypical context for entrepreneurship scholarship, I am also enacting the spirit of curiosity and confrontation which such approaches entail. And I am making no apologies for the highly personal, idiosyncratic - and hence subjective - research process: 'the scholar that practices contextualization as a way to affirm the problem of understanding the meaning of the text has also rejected the idea that there is one true connection between text and the world. There are many' (Steyaert, Hjorth, and Gartner 2011, 5). With that said, allow me to introduce you to the organizing context within which this study has unfolded, the punk rock scene, and Rancid.

\section{Rancid, punk rock and the DIY ethic}

Cultural sociologists have turned their attention to music scenes, which they contrast with the $80 \%$ of popular music emerging from the 'Big Five' multinational corporations (Petersen and Bennett 2004, 4; Peterson 2000; Negus 1999). The scene is characterized by 'small collectives, fans turned entrepreneurs, and volunteer labour' and as such 'this sort of do-it-yourself (DIY) industry represents an important site' (Petersen and Bennett $2004,5)$. In the music industry, authenticity work has involved managing the twin demands of tradition and creativity, demonstrating freedom from corporate 
manipulation, exhibiting congruence between personal lifestyle and creative identity, status identity (perhaps as a marginalized person) and being accepted as belonging to specific subcultures or scenes (Peterson 2005, 1085-1089; Jones, Anand and Alvarez 2005, 893-894). Punk rock scenes, in particular, are based upon opposition to corporate capitalism, and their characteristic DIY ethic of cultural production is framed as an imperative to independent cultural action:

The DIY ethic states that Punks should not be content with being consumers and spectators but instead should become active participants in creating culture by starting their own fan magazine..., creating their own record labels, starting their own bands, and creating a network of venues for live performance. (Roberts and Moore 2009, 22; see also Spencer 2008, 11; Moore 2007)

Punk rock's DIY practices can be read as creative collective organizing both of everyday life and of cultural production: 'punk, as a technology of rebellion, works most effectively (and affectively) when the process of artistic composition exists through a process ... of bringing together and enacting other ways to live and be together in the world' (Shukaitis 2012, 126; Spencer 2008, 238-239). The practice of punk rock is inherently to do with creating otherness, and hence - however formulaic the institutionalized routines of the genre may seem - it has a claim to be seen as a relevant site of mundane entrepreneurship at the margins of society. Punks constitute an unexplored group of missing (everyday) entrepreneurs, placing themselves outside the core institutional power structures of the music industry, and explicitly engaging holistically with alternative modes of production, consumption and living. ${ }^{4}$ As such, this social site of entrepreneuring is a promising context for the study of alternative forms and meanings of entrepreneurship.

Thompson $(2004,3)$ identified seven major scenes in the 35-year history of punk music thus far. These seven scenes comprised thousands of members, each with their own distinct character, and include San Francisco's East Bay Punx. Rancid emerged from this community, and the band's founders are from working class backgrounds in lowincome parts of a city noted for its heritage of protest (Moore 2004, 319, 2009, 50-52). In 1992, Rancid's first EP was released with the East Bay's then newly launched Lookout! Records, with founding members Tim Armstrong, Matt Freeman and Brett Reed (later joined by Lars Frederiksen). The band then signed to punk rocker Brett Gurewitz's independent Epitaph, producing the self-titled Rancid album in 1993. It was with their second album, Let's Go (1994), that Rancid began to experience substantial, national commercial success, partly due to their single Salvation, ${ }^{5}$ and perhaps also attributable to their opening on tour for the Offspring, who were then leading the mid-1990s punk rock revival. At this point, with punk suddenly highly desirable from a market perspective, Rancid were inundated with offers to sign to a major record label; even Madonna was in pursuit of the band. However, Rancid chose to stay with Gurewitz's Epitaph since: 
The beauty of being signed with Epitaph is that we have complete artistic freedom. We don't have to compromise..... We can record any album we want to record. We do everything there. We have complete control over our, um, product. I think product is the right term that is used in the biz. ${ }^{6}$ For a major company, an album and a band will always be a product. Epitaph is not a major company. We're a band. (Lars, NYRock)

Indeed, And Out Come the Wolves is widely believed to have been named, at least in part, for the band's experiences in being pursued by large music corporations. This third album was certified gold within a year of release, compared to the 6 years which Let's Go took to sell the requisite 500,000 copies. Since achieving this fame (and, indeed, fortune) in the mid-1990s, Rancid have continued to tour and record, as well as experimenting with musical side projects, and other forms of Punk entrepreneurship. Studio albums continued, with Life Won't Wait (1998), Rancid (2000) and Indestructible (2003), as well as other collaborative recording projects. Rancid's subsequent independence has been questioned by some punk rockers since Indestructible was distributed by Warner Music. In 1999, Rancid had signed to Tim Armstrong's new label, Hellcat, a partnership with Gurewitz's Epitaph. Lars, who also produces bands for Hellcat, has said 'for us it's kind of an obligation. We've got the chance to help new bands, so, of course, we have to do it' (NYRock). The band had always printed their own shirts and posters, and this evolved into another company, Machete Manufacturing, which subsequently handled the (US) merchandise for all of Hellcat's bands, before growing until it now commissions and sells merchandise for about 100 punk and rock bands. After a hiatus of 6 years away from the recording studio, Rancid released Let the Dominoes Fall in the autumn of 2009, with Branden Steineckert replacing Brett Reed on drums. In December 2012 the band completed their 20th anniversary tour, and have been working a new album during 2013.

In addition to running Hellcat and Machete, Tim Armstrong sells his own artwork online, as well as crafting records on solo and side project basis (with the Transplants), and also writes songs and produces albums for a variety of artists. One of his latest selffunded and managed venture, launched in 2011, is an occasional series of rock musical television shows, commissioned and released through Vevo, Rock' $N^{\prime}$ Roll Theater. Current drummer Branden Steineckert founded and runs Unknown Studios, in 2004 started a (currently mothballed) skateboard and skate wear company, 20/20, and in 2011 launched a small artisanal project making and selling stash boxes made from old books (Undercovers). Branden's two side-project releases with his band Apocalypse Radio are also explicitly described and promoted as DIY. Lars is part-owner of NYHC Tattoo Studios, in New York, and helped found and run Skunx Tattoo Parlour in Tokyo (which is currently taking a hiatus). Lars performs as a DJ quite extensively, too, and was a major force in the band's regular music programme, Rancid Radio. His bands Lars Frederiksen and the Bastards and the New Firm Casuals are also examples of a continued desire to create and share new side projects. Matt Freeman's Devil's Brigade side project highlights his characteristic gravelly growl, complete with an upright double bass. The current Rancid 
band members are therefore a strong example of how diversified and wide-ranging punk entrepreneurship can be, as well as embodying the DIY ethos. As Tim points out:

We take a different route. We're on Epitaph/Hellcat, and our booking agent is an indie, so we're an indie band.... And we do all our own merchandise - we're not part of some huge merch company. We print our own T-shirts, so we're really an indie rock band in the truest sense of the term. And we wouldn't have it any other way. (Langham interview)

\section{Methodology}

As already noted above, the research process is rooted in pre-awareness of two kinds: first, I brought to the study a critical perspective anchored in contextualized understandings of entrepreneurship, and the special interest in place, power and practice that this entails. Second, I also began the project with a strong pre-awareness of Rancid's story, and their music. Indeed, it was this prior knowledge that led me to believe the group, and their context, merited such study. All my subsequent analysis was, of course, rooted in this very scholar-specific pre-awareness.

The source data for the study comprised a large collection of artifacts - musical, textual, in video form and graphic - comprising Rancid's cultural products, and the critical responses of others to their work. Exploring artefacts which encode, or critique, meanings of entrepreneurship is an appropriate data collection strategy, given the study's focus on alternative social sites of entrepreneurship. I drew on the seven studio albums listed above, which provided not just the music itself, and the song lyrics, ${ }^{7}$ but also 'sleeve note' booklets, lyric sheets, photographs and other graphics, as well as the cover art for the albums. I accessed the band's website (and those of their other ventures), Facebook, Twitter and MySpace pages, as well as (the professional) social media sites of band members Lars, Matt and Branden. Audio and video interviews with band members, and Rancid's (mostly DIY) music videos were repeatedly reviewed. Table 1 summarizes the data sources used for the study, which covers the 20-year period from 1993 to 2012, and comprised 117 songs, 14 media articles, 64 videos and 2 audio interviews of varying length, as well as multiple graphic images and web sources. A total of 65,000 words, and almost $4 \mathrm{~h}$ of video and audio material, formed the eventual database of Rancid artefacts and reviews. Appendix 1 presents a sample of 20 questions which various interviewers have posed to Rancid members, indicating that key topics of relevance for the study have indeed been addressed directly within the data-set. Appendix 2 provides a full listing of all primary sources used in the study.

Initial data analysis was borrowed from well-established qualitative approaches, as a means to engage deeply with the data-set (see, for example, Jack et al. forthcoming). I began by iteratively reviewing the data, looking for patterns, similarities and differences. This involved multiple readings, viewings and listening of the data-set, accompanied by contemporaneous note taking, in a research diary (Easterby-Smith, Thorpe, and Lowe 1999). I was constantly asking myself 'what is going on here?' throughout this iterative 
reviewing of the data (Halinen and Tornroos 2005). Following the constant comparison method, looking for both similarities and differences within the data-set, re-'readings' Table 1. Source material for database of rancid artefacts and reviews.

\begin{tabular}{|c|c|c|c|c|c|}
\hline Source type & Source range & Date & & Units & $\begin{array}{l}\text { Data } \\
\text { count }\end{array}$ \\
\hline Albums & $\begin{array}{l}\text { Seven studio albums: } \\
\text { lyrics, artwork, } \\
\text { sleeve notes }\end{array}$ & $\begin{array}{c}93,94,95,98 \\
00,03,09\end{array}$ & 27,854 words & 117 songs & 703 \\
\hline Text & $\begin{array}{l}\text { Interviews, reviews } \\
\text { \& commentaries }\end{array}$ & $\begin{array}{c}96,98,01,04 \\
09,10,11\end{array}$ & 37,187 words & 14 articles & 468 \\
\hline Videos & $\begin{array}{l}\text { Video interviews, } 19 \\
\text { webisodes, Rancid } \\
\text { music videos }\end{array}$ & $\begin{array}{l}95,00,03 \\
04,05,06 \\
09,10,12\end{array}$ & $2 \mathrm{~h} 55 \mathrm{~min}$ & 64 videos & 394 \\
\hline \multirow[t]{2}{*}{ Web sources } & $\begin{array}{l}\text { Web radio; podcasts; } \\
\text { Facebook; Twitter; } \\
\text { websites }\end{array}$ & 2012 & $\begin{array}{r}250 \text { tweets, } 6 \mathrm{w} \\
\text { Facebook }\end{array}$ & $\begin{array}{l}\text { nterviews } \\
\text { ws) } \\
\text { ebsites \& } 153 \\
\text { posts }\end{array}$ & 205 \\
\hline & 65,000 words, and alm & st $4 \mathrm{~h}$ of video o & \multicolumn{2}{|c|}{$\begin{array}{l}250 \text { tweets, } 6 \text { websites \& } 153 \\
\text { Facebook posts }\end{array}$} & 1770 \\
\hline \multicolumn{6}{|c|}{$\begin{array}{l}\text { continued, along with the making of ever more detailed notes, or memos, in my research } \\
\text { diary until few new insights occurred (Glaser and Strauss 1967; Bo"'hm 2004; Alvesson } \\
\text { and Sko"Idberg 2000; Silverman 2000). This process was punctuated by frequent breaks } \\
\text { to read the research notes, and to reflect upon the insights and themes thus garnered. } \\
\text { The methods used are not intended to replicate 'pure' grounded theory development, } \\
\text { since analysis was preceded and accompanied by exposure to relevant theoretical } \\
\text { material. What has been called instead semi-grounded analysis permits 'empirical } \\
\text { research which is informed by prior theoretical understanding, but which is not so } \\
\text { determined or constrained by this understanding that the potential for making novel } \\
\text { insights is foregone' (Finch } 2002,57 \text { ). Enhanced understandings of extant conceptual } \\
\text { work, and the generation of themes from the data, developed in parallel iterative } \\
\text { processes, in a reflective spiral (Alvesson and Sko"ldberg 2000). Eventually, from the } \\
\text { many themes which I found in the data, I began to develop something approaching a } \\
\text { pattern, as I identified - or perhaps constructed - connections and overlaps between } \\
\text { themes. At this stage, a first draft framework was developed to summarize my reading of } \\
\text { the data, and was tentatively validated and illustrated by populating it with examples, } \\
\text { quotations and images from the data-set. This initial framework was shared with } \\
\text { informed colleagues through a series of conference and workshop presentations, and } \\
\text { their questions and critiques helped to highlight inconsistencies and overlaps. (Like } \\
\text { entrepreneurship, our creation of new knowledge is indeed a collective activity.) }\end{array}$} \\
\hline
\end{tabular}


Thus prepared with a very thorough immersion in both theory and data, and abundant insights from colleagues, I returned to the data-set and began extracting all specific exemplar data relevant to the study, gathering them together into a digital spreadsheet. This resulted in a database of 1770 exemplar data, which I then open-coded, trying to stay close to the language of the artefacts themselves. The objective at this point was to develop in 'in-vivo codes, which, as colloquial interpretations of the phenomena, are taken directly from the language of the field of investigation... components of "theories" formulated personally by the producers of the text in question' (Bo"hm 2004, 271). Firstorder coding was then followed by a subsequent round of second-order coding, which gathered the (first-order) codes into 24 cognate categories of data (Bo"hm 2004, 273274). These 24 categories form the building blocks of the study's findings. Figure 1 provides an illustrative example of this process, for three of the open first-order in vivo codes which were subsequently incorporated (with several others) into the category 'Marginality', adapting Corley and Gioia's $(2004,184)$ similar diagram.

For each of the 24 second-order categories, the pattern I constructed contained an opposing but closely related counterpart. These 12 contrasting pairs were held in tension throughout Rancid's discourse and praxis. Striking examples included themes for both resistance and acceptance, for caring and combating. My findings thus showed a tendency for paradox, defined as 'contradictory yet interrelated elements that exist simultaneously and persist over time' (Smith and Lewis 2011, 382). This paradoxical framework was relayed to various members of the punk rock community to assess its inherent validity within the context under study. All those engaged, including Rancid's drummer Branden Steineckert, expressed their approval of the basic framework, and the themes contained within it. I was especially grateful for this reflexive support.

The final stage of analysis involved applying the analytic frame described above - place, power and practice - to these 12 pairs, reflecting on whether they could be described and analysed using one of these three dimensions, and, if so, which. Data pertaining to each element were then extracted to separate files, and critically analysed.

After some trial and error, further reflection and writing drafts of analysis and findings, a point was reached where categorization and consideration of the 24 themes, and the 1770 exemplar data contained therein, appeared to have been adequately carried out. It is the results of this critical process to which we now turn. (Figures 2 and 3 present a graphic illustration of the methodological process.) 
Los Angeles take your dreams away Burnin' on the ground...

And I say Nobody knows me, I'm all alone Ah yayayayay I gotta go

It's a Hollywood bus stop and the party's over

It's about people coming to LA, not making it out and getting caught up in all sorts of bad stuff.

Rancid commentary, LA River

Frederiksen believes it always will be relevant. For a pretty simple reason really. ("There's always going to be some kid somewhere who's disenfranchised, or an outsider, or feels like he doesn't belong,")

Lars Rock FM Interview

Combines Dylanesque portrayals of downand-out streetlife and personal experience with tunefully concise, dynamic songwriting to create an enduring body of work

Epitpah Band Description

Loss of life, hope and

dreams, even in the city of dreams

We understand what it means to hit rock bottom

Rancid Commentary, Up to no Good

I've been stupid as a kid.I've been a junkie, I've been homeless.[...] My identity for three or four years was a junkie

Lars Skratch Magazine Interview
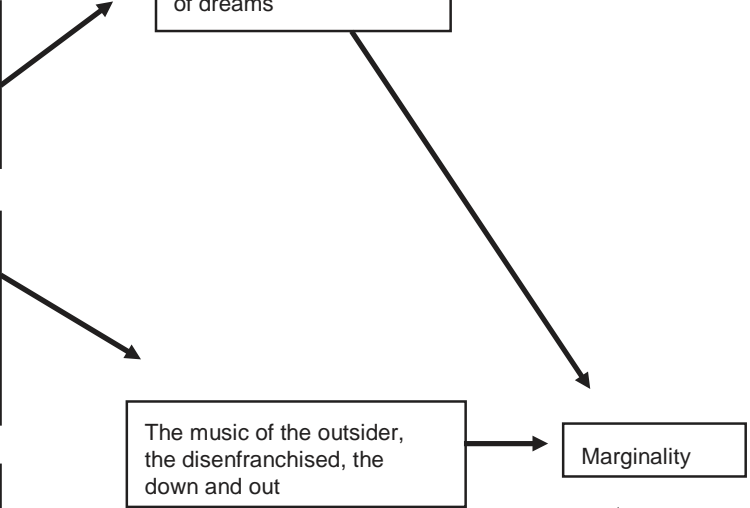
the disenfranchised, the

Tim semed to have hit rock bottom. Even his mother wouldn't let him stay at her house anymore, and he wound up in a Salvation Army shelter, working for them in exchange for a bed.

Livermore, Journey to the End

Figure 1. Illustration of moving from data, to first and second order coding. 


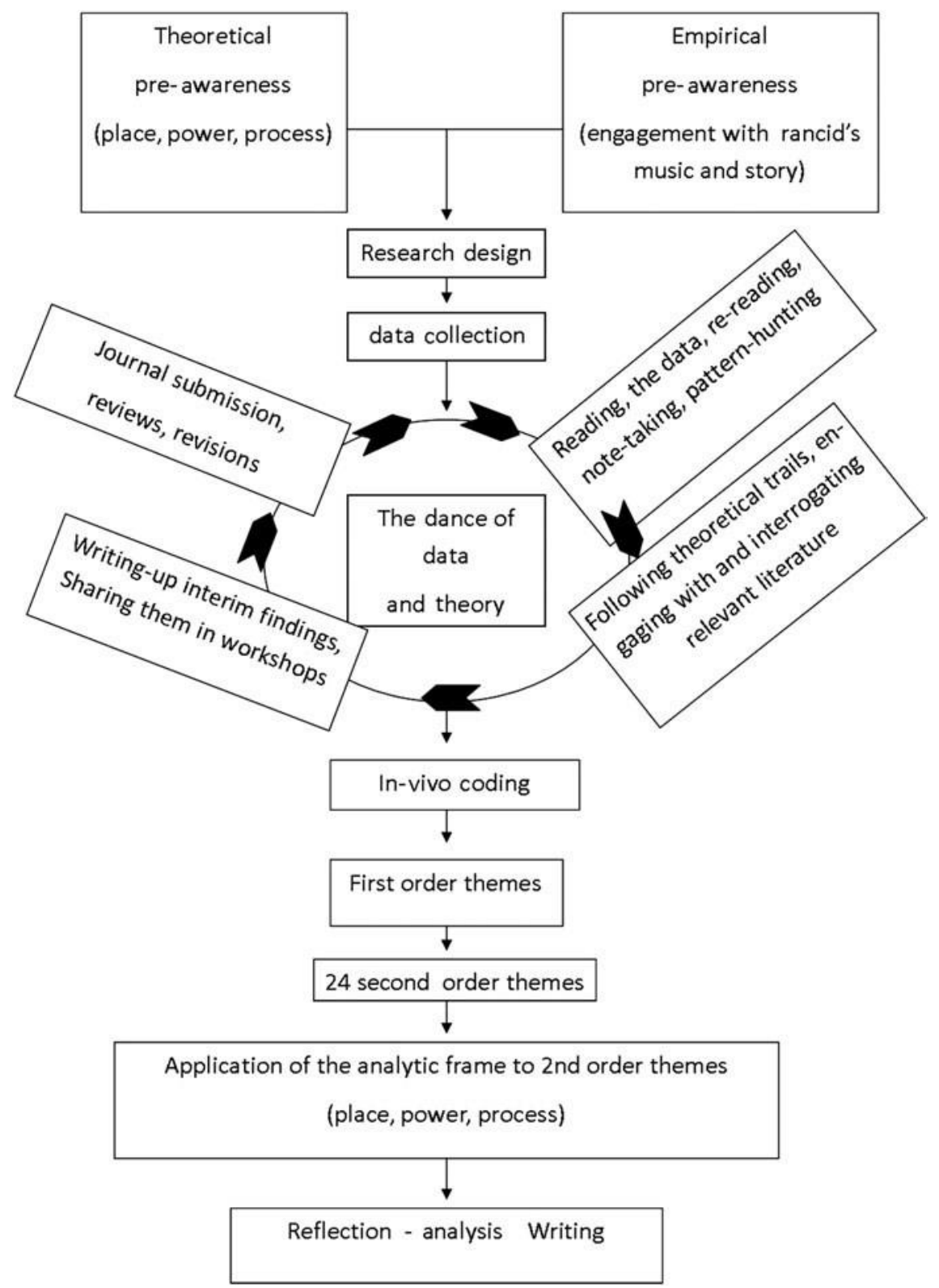

Figure 2. Methodology. 


\section{Findings}

\subsection{Power}

The four paradoxes which I found to express Rancid's social construction of power in alternative entrepreneurship are marginality and leadership; radicalism and tradition; autonomy and constraints; and resistance and acceptance. Resistance, autonomy, radicalism and marginality dominated in terms of prevalence within the data-set, highlighting the critical and heterodox nature of power for these alternative entrepreneurs, as the subsequent presentation of findings will show. Figure 4 sets out the proportions of these four paradoxes within the data, whilst Table 2 presents additional empirical data illustrating each of them.

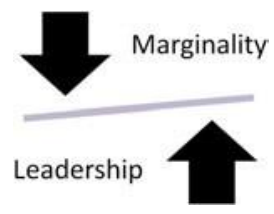

Marginality is the most frequently encountered theme in the entire data-set, with 260 observations. To a much lesser degree, the converse power of leadership offsets this trend ( 31 data). Many of the bands' songs are laments for the marginalized, the lost and left behind, including junkies, criminals, gangsters and hookers, of whom they sing the 'living and dying and the stories that are true' (Lyric, Time Bomb). These songs are often eulogies for friends and family whose marginality has killed them, whether by suicide, homicide or drug and alcohol abuse: 'Jackyl was one of the one's that perished, he was one of the ones, that was already saved' (Lyric, Daly City Train). Rancid have themselves journeyed from extreme marginality, and the inherent powerless that accompanies it, including, for various band members, homelessness, deep poverty, drug addiction, alcoholism, an abusive home and jail. These experiences, and the struggle to overcome them, are seen to add authenticity to their explicit tackling of issues of exclusion, exploitation and alienation. In a 2004 interview, for example, a journalist says to Lars

I love how your music takes on the title of "keeping it real" both musically and lyrically. You tend to stick to the ruggedness of punk rock, like, by talking about life on the streets, the rough past and the tough future'. (Skratch Magazine)

As the band themselves note, 'we understand what it means to hit rock bottom' (commentary, Up to no Good). Entrepreneurship has a history of being a refuge for the outsider who finds themselves on the margins of power, due to race, religion, immigration or gender, an issue I will return to later in the manuscript. 


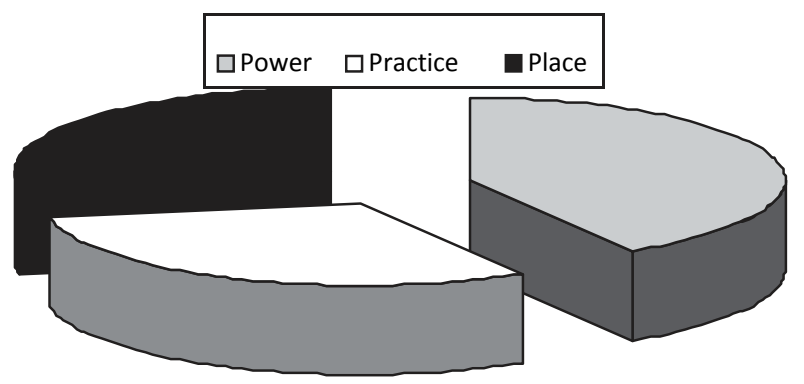

Figure 3. Dimensions of alterity.

Over time the band's survival, success and perceived authenticity have given them a role as 'senior statesmen' in the punk rock community. Mostly, this leadership is expressed through providing support for other (younger and older) musicians through Hellcat Records, Machete Manufacturing, Radio Rancid and the organization of showcase tours. Lars explains to DJ Hikaru that 'Tim kind of had the idea of this residency ... support these bands, and support the scene, cuz that's what Rancid's always been about, you know'. However, Rancid decline to give guidelines to other people on music, ethics or politics, explicitly refusing leadership in almost all cases - 'if there is any message that I have politically, it's: think for yourself' (Lars, Skratch Magazine interview, 2004). The single exception to this rule can be found in direct critiques on violence and schisms within marginal communities, whether along racial or musical grounds. As they sing in 'Avenues and Alleyways' 'actions could erase all the fear that we suffer, people segregated no one understands each other'.

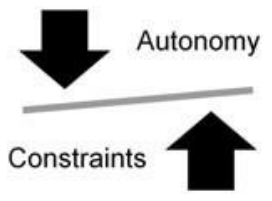

DIY culture espouses independence from mainstream industrial sectors through autonomous action. The highly entrepreneurial nature of this autonomy is made very clear by Rancid: 'the spirit of punk rock involves taking risks. It's about questioning authority and not subscribing to society's norms and not falling into the rut and becoming a sheep. Without risks you'll never discover your potential' (Rancid commentary on Let the Dominoes Fall). This is most evident in Rancid's self-production of their own artefacts (songs, band shirts, videos, posters, albums) that grew into their venturing through Hellcat, Machete, Radio Rancid and independent tours. It is signalled too in the aesthetic of the artwork on albums, with the continued use of graffiti-style stenciling, hand-written lyric sheets and distorted black-and-white images. 


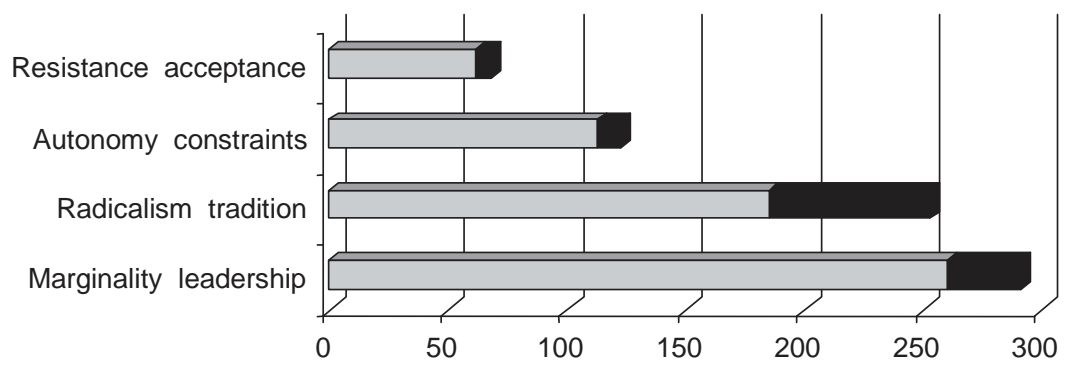

The speed and directness of their music are also an ongoing enactment of the DIY ethos. Another important form of autonomy inherent to punk rock is freedom from caring about what other people think of one, a common theme in Rancid's lyrics and Interviews: 'I ain't worried about a god damn thing; I hear them talking. I ain't listening' (Lyric, 'I ain't worried'). Rancid have also maintained autonomy from management control, and kept control of their own decisionmaking. This freedom has long been argued by the band to be an integral part of their longterm relationship with Epitaph Records:

We record the kind of album we want to record. We pick the artwork for the album. We decide on the single releases. We pick the studio, the people we're going to work with, the booking, the people who'll go on tour with us. It's all our own decision. Nobody tries to interfere.

Nobody tells us what to do. (Lars, NY Rock interview)

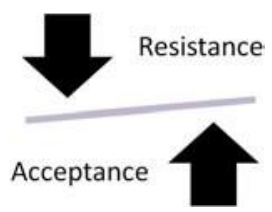

Evident to a lesser degree in the data, Rancid consistently place boundaries on their own autonomy. Most importantly, Rancid talk a great deal about honesty and integrity in their work, about the need to keep it real, to continue being true to yourself: 'make sure you stay true to yourself, and you follow your heart, man, you know what I mean, man' (Tim, Hikaru interview). Their venturing actions are constrained by the personal needs of the band members, as mentioned already, as when 'we didn't make a record for six years, but Lars had a little boy, Matt had two little boys, and I did a solo record. So we're patient, we work on our own time clock' (Tim, Shockhound). The band is bound by their own desire to maintain their peripheral locus, to be firmly embedded within the ethos of punk rock marginality. However, these constraints are self-selected, and carefully considered: 'it's not about paying your dues if you do it out of love' (Lyric, Unwritten Rules). 
Table 2. Power themes and illustrative data.

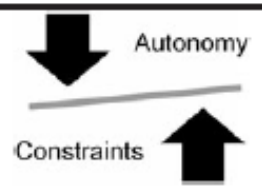

'The secret is not succumbing to the pressures from anybody else. We've just always done our own thing because that's what we're accustomed to do... You get conditioned at an early age to just keep walking and do things on your own path.' Lars, AV Audio interview

'Collectively, we make one brain. There are a lot of smart managers out there, but we like to make our own decisions and take our time.'

Tim, Shockhound interview

'The moral of the story? You can never go wrong when being true to yourselves, a rule Rancid have always lived their lives, and flourished, by' Epitaph, band description

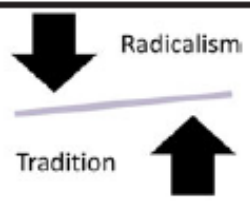

'The Wall Street Bailout is crooked and stacked The burdens gonna end up on the working man's back'

Lyric, That's Just the Way it Is

'Is this human freedom, Hedonistic excess? Junky consumerism, Mass-production, toxic sickness,' Lyric, Bom Frustrated

'You're working like a monkey who's been trained by a sick junkie on a mission to get money for a new suit and tie' Lyric, Outta my Mind

'And we headed on down to LA and recorded our first record at what to me was the world famous West Beach studios, cuz that was where NOFX had recorded, and Offspring; Bad Religion, and Pennywise' Tim, Webisode 2

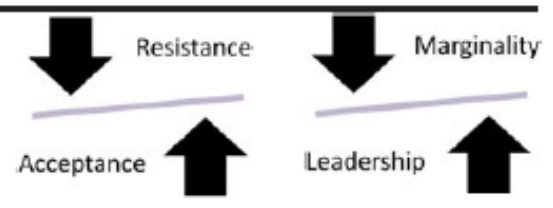

'Fat cats eventually sleep to long while the starving rabble stay awake waiting for a moment to strike. The graffiti on the walls will always leave clues. Follow them' Rancid commentary on Let the Dominoes Fall

'Let life go where it takes you. Take what comes no matter what it is. There's only a certain amount of stuff that you have control over so just let it go'

Rancid commentary on Let the Dominoes Fall 'With a 12 gauge double barrel lyric gun, Shoot 'em up free and smack down' Lyric, Crane Fist

'Corporate liberal bullshit, ruling fucking class, take your fucking money and shove it up your ass' Lyric, Injury
'So I drank like a fish and I crawled like a rat. Through the city of shit I ended up on my back' Lyric, Who would have thought

'I was down on my luck working for the salvation army The shelter is where I reside'

Lyric, Salvation

'combines Dylanesque portrayals of down-and-out streetlife and personal experience ... to create an enduring body of work'

Epitaph note, And

Out Come the

Wolves

'War between races, War between lies, War between something that was deep inside' Lyric, As One 


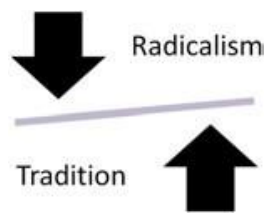

Like many of their fellow punk rockers, Rancid espouse a radical anti-establishment stance, with specific attacks on the dominant power structures of the mainstream media, large corporations, Wall Street, the police, consumerism and US foreign policy. Typical critiques assert that 'the land of liberty has been betrayed by the monster corporations; the monster won't stop till it lays waste to everything' (lyric, 'This Place'). The attacks on commercial consumer capitalism made by these alternative entrepreneurs are sustained and direct: 'you're selling sexism, you're selling racism, you're selling anything you get your fucking hands on' (lyric, 'Antenna'). Their music also contains explicit homages to the protest song tradition: 'this song is ... a protest song in the folk tradition of Woody Guthrie' (Rancid commentary on Let the Dominoes Fall).

Balanced with this radicalism is a form of empowerment drawn from a range of rock music traditions. This is expressed by constant references, in interviews, lyrically and musically, to folk songs, rock and roll, punk rock, reggae and ska. It is shown in mentions of specific musicians, their style and influence, band shirts worn by Rancid, band tattoos inked on their bodies and videos shot in iconic locations (the East Bay's Gilman, New York's CBGB). Even the classic Rancid image of Tim, head bowed over his knees on a step, on the cover of And Out Come the Wolves is a graphic reference to this tradition, echoing Minor Threat's eponymous EP artwork. ${ }^{9}$ Rancid are thus firmly embedded within a punk rock musical (and political) heritage: 'I heard GBH, I made a decision, Punk Rock is my religion' (lyric, 'You Want It, You Got It'). Rancid remind us elsewhere that their radical anti-market stance is itself part of a very long tradition, with Tim's project Rock'N'Roll Theater bringing 'the 14th Century epic poem, Dante's Inferno, roaring into the 21th Century with a new take on greed and corporate corruption' (Hellcat Records description). Similarly, the band balances tradition and radicalism in their reference to 'Chaucer's Canterbury tales, when three men find a pot of gold and end up killing one another in the name of greed' (lyric, 'Poison').

Rancid engage with dominant power structures largely through resistance: 'Don't get crushed in the iron fist; Resist, resist, resist, resist, resist!' (Lyric, 'Out of Control'). This is most obvious in the writing of protest songs, some of which explicitly promote and celebrate violent resistance, and others of which predict the coming of dramatic social change: 'times are gonna change, change or step aside; It's my point of view that took you by surprise' (Lyric, 'Avenues and Alleyways'). But then, entrepreneurship too has often been about challenging the status quo, including those expressed in established power structures. Creative destruction is always, to some degree, an act of resistance against the establishment: 'do you know where the power lies, and who pulls the strings? 
Do you know where the power lies it starts and ends with you' (Lyric, '11th Hour'). Paradoxically, though, there are several songs which emphasize accepting the way things are, with an almost fatalistic tone, as in the title song from Rancid's latest (2009) album, 'Hey ho, let the dominoes fall: no, no, no, I ain't got control' (lyric, 'Let the Dominoes Fall').

\subsection{Practice}

The four paradoxical tensions relating to Rancid's practice dimension were, in order of prevalence, play and work; making music and recording; journeying and returning; and caring and combating (see Figure 5 and Table 3).

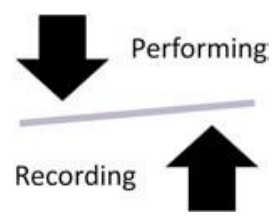

Making music (77 data) through shared creativity is the core Rancid practice, balanced by its counterpart, recording (75 data). Performing is prioritized above recording, with Tim repeatedly using a very graphic metaphor: 'to me, the records, and the singles, that's just the menu; the meal, that's the show - the band up there, doing their thing' (Guitar Center podcast). Indeed, recording as far as possible mimics live performance, with the same

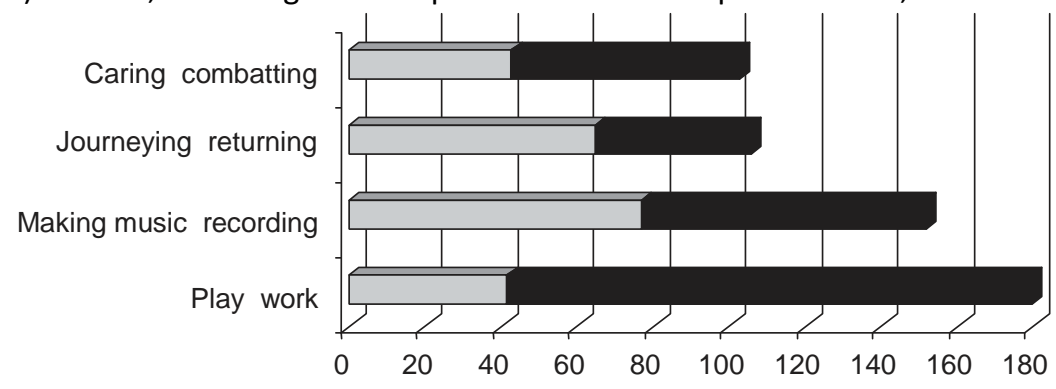

Figure 5. Practice.

set-ups used for the guitars and bass, and very spontaneous, almost live takes. The live shows, and touring experience, are clearly the essence of Rancid's performing practice: 'that is my life, dude. That's my whole fucking life. ... I'm on tour, I'm in my band, that's what I do, you know what I'm saying?' (Matt, 1996 interview). Creating music, writing songs, performing, playing a show - all of these practices highlight Rancid's ongoing innovative, emergent cultural production. Ever-changing, always engaged with the 'client', perpetually new and mutable, these practices are highly entrepreneurial. ${ }^{10}$

Turning to recording, albums are presented as documenting where the band finds themselves, personally and politically, at a given point in time. As noted already, they are 
kept as close to a spontaneous, live performance as possible, with songs often recorded in a single take, and even written just the night before. Songs keep changing after the album, too: the last album was immediately re-recorded in an acoustic version, mostly in hotel rooms, on tour. All of this is argued to make the recording practice authentic, honest, true and real. Mainstream entrepreneurs may find resonance in the notion of a product or service being a 'document' which briefly crystallizes, freezes, the firm's creative practice at that point in time.

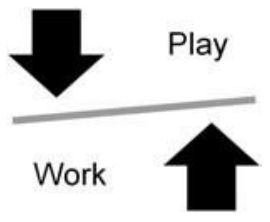

There is a strongly ludic element to the band's making of music; 'it really is just about playing music now for Matt, Tim and Lars' (Livermore, Journey to the End). This is not uncommon in cultural entrepreneurship, especially where 'playing' an instrument is involved. It is also close to some modern expressions of anarchism. The joy, spontaneity, passion and frivolity of this practice are remarkably evident in interviews and on videos. 'We were all singing and jamming, it felt like a celebration and anthem which in turn is exactly what it became' (Branden, commentary on Let the Dominoes Fall). The inherent pleasure which this entails is explicitly referred to, repeatedly, as this example shows: 'I love it so much. It's my life. I love what I do, I love the people and I love the relationships I've cultivated' (Lars, The Rock FM interview). When describing their new musical ventures, too, the language used tends to focus on playful concepts such as creativity, fun and joy. Tim talks about his Rock'N'Roll Theater television show as being 'one of the funnest things I've ever done with music. It was crazy, it was a fucking party' (Tim, Guitar Center podcast).

Yet, held in tension with these playful practices are tales and experiences of tremendous hard work, which include months and months of touring, years of living hand-to-mouth and persisting doggedly in doing things their own way: 'when the roadblock's in the way, we're gonna run around it, when the stop sign's in the way, we're gonna run through' (lyric, 'Road Block'). When Rancid first formed, they cleaned the toilets in Gilman, in exchange for rehearsal space (Livermore, Journey to the End). Equally, Rancid have demonstrated extensive engagement with all aspects of making and sharing their music: making videos, doing their own artwork, printing their own shirts, starting their own label, creating spin-out projects. In summary, 'everybody's got so many projects going on in the band, and that's one of the beautiful things about Rancid ... we're all a bit workaholic, and we like to stay busy, and we like to stay creative, and moving, you know' (Brandon, Dog and Deuce podcast). This entire shared creative endeavour has involved labour, commitment and perseverance: 'work hard - if you love it man, it's not work' (Tim, Guitar Center podcast ${ }^{11}$ ). Working hard for Rancid means working with 
Table 3. Practice themes and illustrative data.

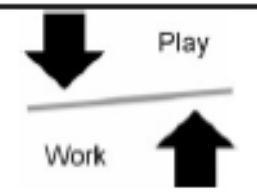

'Somehow none of it seems like a job at all, more like a bunch of guys who are the best of friends and would be hanging out together anyway, and somehow while they're hang ing out, all this stuff gets done'

Livermore, Joumey to the End

'T'll ask kids in younger bands 'Do you want to know the Rancid plan for success?' They'll say 'Yeah!' and I'll tell them this - 'There is no plan. Just be creative with your brothers.' Tim, LA Times Music Blog

'It's mostly hard work and determination, long rides in the back of a car or a van, scraping by for years on not much more than cheese sand wiches and hope' Livermore, Joumey to the End Article

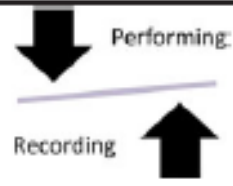

'Just wanna play one more show, make some music with my friends'.

Lyric, On the Highway

'Even in Rancid, we just talk about what we're going through at the time and what we're facing and the shit that we dealt with when we were kids. It's just a stream of conscious, going through shit with your music and using it as way of therapy and a way of getting a lot of things out.'

Lars, Skratch Magazine interview

'When we' re in the studio we try to capture what we do live, cuz I mean that's what we've been doing since we were kids is playing live, right? So we want to capture that' Tim, Webisode 7

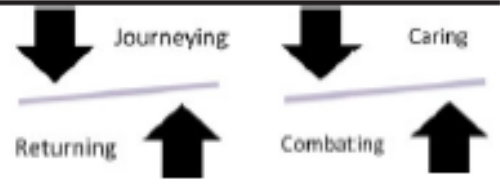

'So, this is the making of Rancid 7, so, come along, this is the joumey Man'. Tim, Webisode 4

'You moved up the ladder at a very rapid speed we moved methodically and calmly'

Lyric, The Way I Feel

This will be enough to keep me on the road livin, Good every night, in a different city I'll be sleepin,

Lyric, Memphis

'We're dniving around. We're playing our songs to a different audience every night. It's fun but it takes its toll' Lars, NY Rock Interview
'Radio is a song about music and about how when I was a kid that was all I had. I didn't have nothing. I didn't have money. I didn't have hardly any friends.

And music was like my salvation, you know' Tim, MTV Europe interview kind and I try to do what's right' Lynic, Get Out of $M y$ Way

' $\mathrm{T}$ ' $\mathrm{m}$ a hyena fighting for lion share, sometimes the lions share ain't there' Lyric, Hyena

'They even flip a stiff middle finger to naysayers who predicted their demise on the kickoff single, 'Last One To Die', Tom Lanham, Shockhound 'I try to love man- 
people, whether writing songs, making records, touring, creating side projects or initiating collaborations. Many of these co-operative projects (albums, shows, tours, bands, products) are with other musicians, and this is seen as generating even more creative innovation: 'I love collaborating, you never know where it's going to land, where it's going to end up. It could go in any direction' (Tim, Guitar Center podcast).

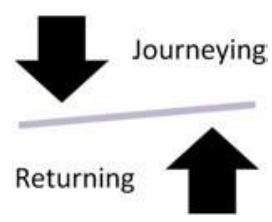

Rancid - like many 'mainstream' entrepreneurs - often use the journeying metaphor to describe their experiences: 'staying the course on the long, strange punk-rock trip' (AV Audio interviewer). This metaphor depicts progress, moving onwards, overcoming barriers, taking some fellow travelers with them and leaving others behind. It is signalled in video and graphic images of the band on the road, of highways, of airports, of aeroplanes and of maps. Indeed, more than once, the songs themselves are seen as encapsulating the journey, as providing the means by which Rancid make sense of their own path. For example, Tim, filmed buying a notebook, tells the camera 'I've got to pick up a notebook, you know, to document my travels, to explain where I've been, to tell me where I'm going, and, ... to turn 'em into Rancid songs, you know. The lyrical process going forward' (Webisode 6). The unusual length of this journey, with Rancid surviving as individuals and as a band for so many years, is often invoked, and their persistence in so doing: 'I stood up every single time I fell' (lyric, 'The Wolf'). Personal journeys from the marginality of alcohol and drug abuse, or extreme poverty, are also celebrated as a hard road, long travelled: 'knuckle up, buckle up, the ride's getting rough but I will not lose my mind' (lyric, 'Hyena').

Yet the journey is always held in tension with Rancid's 'returns', the endless cycles of touring, often the same cities, over two decades 'like a movie I've seen twenty times' (Tim, commentary Let the Dominoes Fall). The places they cycle through inform Rancid's writing since 'on tour, it's like, you're in different cities pretty much every night, so you always have your creative juices flowing' (Lars, Skratch Magazine interview). Rancid, too, is always returning to the East Bay, their local grounding and their social grounding in the marginalized edges of the working class. ${ }^{12}$ These returns are echoed in recurring lyrical, graphic, and musical themes and traditions. Returning is not straightforward, or even always comforting. Not everyone comes back home, as the references to the returns of military personal from overseas duty make clear (lyrics, 'Lulu'; 'Civilian Ways'). This is radically different from social constructions of the mainstream entrepreneur, where a 
maverick, pioneering, solo explorer of new territories motif tends to hold sway (Drakopoulou Dodd 2002). But it adds much depth, richness and consistency to complement Rancid's creative and innovative journey.

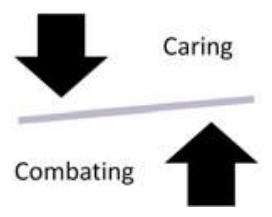

It may be unexpected to hear this band sing that 'compassion heals while duplicity kills' (lyric, 'The Way I Feel'); but hugs, tenderness and declarations of brotherly love abound in Rancid's videos and interviews. ${ }^{13}$ This fraternal care practice of engagement can be seen very clearly in the lyrics of 'Fall Back Down', where Tim credits his Rancid 'crew' with getting him back on his feet after his wife left him: 'if I fall back down, you're going to help me back up again; if I fall back down, you're going to be my friend ...we're going to make it through the darkest night'. Rancid has provided a means of 'soul survival', which drew its members out of marginality, perhaps even kept them alive. Matt explains that 'it helped me stop being alienated. I don't know what the hell I'd be if I didn't have music' (Punk Rock Academy Interview). Care for those who are still marginalized is evident in the band's songs, not least since Rancid feel the need to 'give back everything that you gave me' (lyric, 'Indestructible'). A compassionate refusal to judge others is also evident, as when Rancid sing that London gangster Dave Courtney is 'a legend in the underworld, Robin Hood to the poor', (lyric, 'Dave Courtney'), or write a tender love song to a 'dopesick girl' (lyric, 'Dopesick Girl').

Rancid are also well known for combat as an engagement practice, paradoxically. Rancid agree that 'we've been noted for our combative style' (lyric, 'Locomotive'), which is enhanced by aggressive images, toying with baseball bats on videos and other lyrics: 'you wanna fight l'm gonna win - l'll take you out in a minute' (lyric, 'Rats in the Hallway'). What draws this response from them most is inauthenticity, fakeness and betrayal: 'you're a rattlesnake, you talk that shit about our crew, we hate you' (lyric, 'Rattlesnake').

\subsection{Place}

The place dimension incorporates working class and champion (social space); periphery and centre (industrial sector loci); local grounding and global concerns (geo-political setting); as well as fraternity and community (habitus context). Figure 6 and Table 4 present the findings for the place dimension in summary form. 


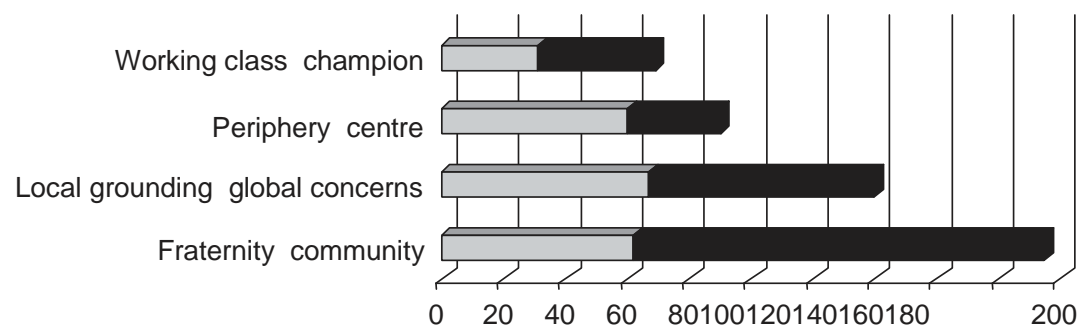

Figure 6. Place.

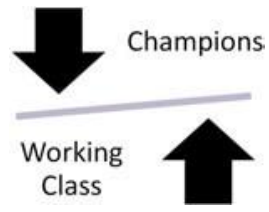

Rancid's social locus comprise both the working class (31 data), but also paradoxically the elite world of the champion ( 38 data). The band's origins are all blue collar working class, as they forcefully make clear in song and comment: 'I am working class culture, seen the bleak side of the American experience' (lyric, 'On the Highway'). Rancid continues to write songs from this perspective, and to discuss their class roots very explicitly as informing their writing and praxis:

You come from that place. You grow up, you live through it, you see people die through it it's your experience. It's always going to be a part of you. It's not like graduating from college or high school; you don't just graduate from the way you grow up. (Lars, AV Club interview)

This social grounding can also be seen in the many images and film shots of factories and labour disputes, which echoes the band's recent comment that 'we feel like the American working class has been left behind, forgotten' (Tim, Webisode 8). Punk rock, as music and lifestyle, is portrayed as a response to the hardships of the blue collar lifestyle, as an authentic voice of escape, support and protest.

This is not Rancid's only social locus, however, with the band routinely referred to as 'punk rock royalty', veterans, myths or legends (Rock FM interview). Indeed, Rancid's financial success, with multiple platinum records, has made millionaires of the band, an almost traditional 'rags to riches' entrepreneurial tale of the American Dream. Although they sometimes celebrate this themselves too, mostly they downplay their commercial and financial success: 'We never fucking changed. We never fucking did. It just happened' (Matt, Punk Rock Academy interview ${ }^{14}$ ). It is the persistence, authenticity and autonomy to which they credit their success that Rancid sings about, rather than success itself or its trappings: 'In a world where people don't hang on too long I belong - Prove me wrong' (lyric, 'I ain't worried'). 
Table 4. Place themes and illustrative data.

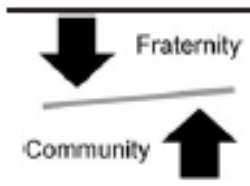

'We're together every day, you know, we bros, brothers, I mean, this is family. I mean, to us, when this is all gone, these guys are stil going to be my best friends in the world.

I love these guys'

Lars, MTV Europe

'Rancid has always been about friendship and family first. There was no outside pressure to have a new record.'

Tim, Metronix interview

'Because of Hellcat, I'm constantly in contact with young artists that are teenagers or in their early $20 \mathrm{~s}$ ' Tim, Shockhound interview

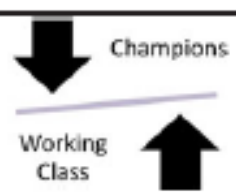
identified with the working class people, because that's where we come from, that's our history'

Tim, Webisode 8

'the working class carries a country that has been rotting inside for years' Lyric, Whirhwind
'Rancid has always

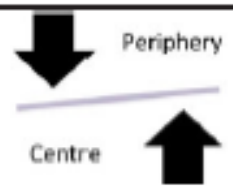

"Another night in the streets for me another night no sanctuary another night come and watch me bleed' Lyric, Another Night

'For ten years we struggled to survive, and I spent half my time living in shelters and detox centers.'

Tim, Hit Parader Interview

'I sit back and I think its funny You we're so wonried about the money Cloudy days are looking sunny' Lyric, You want it, You Got It

'We're the kings of the low income block - Wom out sneakers skinheads Mohawk' Lynic' I ain't worried
'It was as if someone had opened a door to the East Bay, shone a light on it, and, as someone once said about the Califomia Gold Rush, 'the world rushed in.' , Livermore, Joumey to the End

'The band recorded.... at George Lucas' Skywalker Sound Studio, where spider web body art isn't quite so typical.' August Brown, LA Times Music Blog

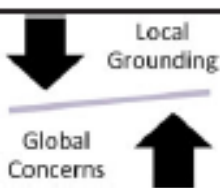

'In so many ways you are where you came from, it's engrained in you. It can shape you and define you as well as the experiences you may have throughout your life.'

Rancid commentary on Let the Dominoes Fall

'Rancid ... as a band have always been imbued with a sense of place: the blue collar neighborhoods where they grew up, their place as individuals within their band, their band as part of a movement and their evolving sense of place in relation to the world

at large.'

Epitaph, Band

Description

'For $24 \mathrm{~h}$ on the Ivory Coast, They release soldiers from their post, They dedicate champagne, for a toast, They pay dividends to the country's host.' Lyric, Ivory Coast

'Boom boom boom look around There's no more roof no more house, no street, no town, shot down'

Lyric, Let me Go 


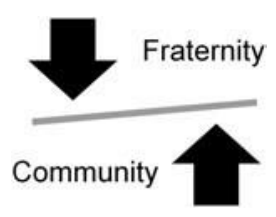

Rancid's habitus includes their being placed both within a tight fraternity and within the wider community of punk rock. The brotherhood of the band itself is a primary commitment to each other. This is depicted as a very tight inner circle, whose personal needs and relationships are consistently put before band work. For example, health issues, paternity 'leave' and marriage breakdown have all been cited as causes for breaks in touring and recording. Lars explains that 'Rancid's a family first...that's what's always has come first for Rancid, is we're a family first, we're a band second' (Warped Tour interview, 2003). Similarly, Tim says that 'it's the best thing in the world, to have four of

us...we're all like brothers' (2006 TV interview). A paramount social locus of authenticity for Rancid, then, is the fraternity of the band itself.

This is not the only place which sustains Rancid's venturing, however, which also draws heavily upon the bands' grounding in the wider community of punk rock. Strong identification with multiple generations and stakeholders in the punk rock (and related) community is shown through their work to promote and produce younger bands, and their closeness to fans, including them in music videos, and sharing photos of their tattoos. When Lars is asked what the Ramones meant to him, for example, his discourse is highly intimate and forceful 'Wow, it's like ... (pause)...surrogate parents, ya know what I mean, their records saved my life' (Blairing Out, video interview). Similar tales are told of many other first-generation punk rockers, who supported Rancid when they were younger, and family metaphors once more abound. For example, Brett Gurewitz, from vintage punk band Bad Religion, signed Rancid to his label Epitaph, produces most Rancid albums and encouraged the formation of Tim's Epitaph offshoot label Hellcat. When asked about Brett Gurewitz' ongoing role in their work ${ }^{15}$ (and, often, why the band turned down millions of dollars to stay with Gurewitz' Epitaph), their consistent response invokes his belonging to the punk rock community: 'he was punk before we were punk, he toured in a band before we toured in a band, he's in Bad Religion, man' (Tim, Guitar Centre podcast).

Just as Gurewitz, and other members of the older generation, supported Rancid's early days, so the band also engaged with younger punk performers, as has been extensively discussed already. As well as punk musicians, however, the band is strongly embedded in the community of their supporters, who they routinely include on their videos, and thank frequently via social media for attending shows: 'we have real loyal people that follow us and will come out and see us play, and that's golden' (Tim, Shockhound). The band often talk about this community, and its music, as having saved 
them, and both they and other commentators have noted the importance of belonging to Rancid: 'I didn't even think about playing, I just wanted to have some cool place to be...it was that fucking innocent. ... how hungry was the whole climate? It was like we were starving' (Tim, Journey to the End). It is perhaps this sustained need for social embeddedness which allows them to sing to their fans that 'we know who you are and we've been where you've been' (lyric, 'You want it, you got it').

Many of the band's ventures have emerged directly from this community, as the Hellcat Records, and Machete Manufacturing examples show. Similarly, Lars became a partner in the classic New York Hardcore Tattoo Parlour when other musicians called him up and invited him to join. His rationale for investing was articulated completely within a community discourse: 'those guys are, you know, my homies, my brothers. So of course it was a no-brainer' (Lars, 'Behind the Ink' video interview). Collaboration within the punk rock community (and with the related realms of tattooing and skateboarding) has generated multiple new Rancid projects and ventures. No discourse of competition is present anywhere within the hundreds of data gathered and analysed, however. ${ }^{16}$

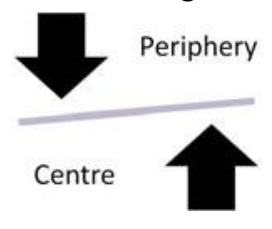

Rancid's geographical locus is on the urban fringes, in areas of socio-economic deprivation: 'blown out and abandoned hotel buildings that were once new in the times of great American prosperity. Cold fronts of society's collapse blow in, where poverty and despair now live' (Rancid, Commentary on Let the Dominoes Fall). Song lyrics, album artwork, and - especially - video settings locate Rancid firmly in this milieu (lyrics, 'Rats in the Hallway', 'Avenues and Alleyways'). Their sectoral locus is on the edges of the music industry, in spite of being pulled towards the mainstream music industry's centre, by offers of million dollar contracts. As one journalist noted, 'it's truly unusual for a band to stick with an indie label when they are courted by basically every major record company' (Gabriella, NY Rock Interview ${ }^{17}$ ). However, it is important also to recognize that 'sticking with Epitaph was not just good ethics, it was good business: indie labels, the well run ones, anyway, pay their artists a higher royalty rate and give them far more control over their music and art' (Livermore, Journey to the End).

Yet, they have journeyed towards the centre of the Punk Rock scene, becoming a hub of ventures and projects. Rancid have become a centre of attention, too, which is often decried by the band: 'the ground is fertile and the grass is green so many things to be seen so many bands to be heard just for once can I be ignored?' (Lyric, 'Disorder and Disarray'). 


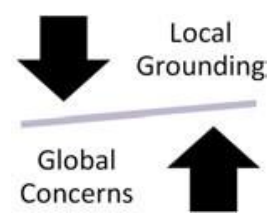

The band explains: 'so much of our history, family.....roots come from the Bay Area' (Rancid Commentary on Let the Dominoes Fall). The importance of authenticity, emergence, keeping it real and somewhat 'underground', touring as a way of life, protest, resistance and working class survival are all framed by Rancid's grounding in the East Bay, as we have already seen. Socio-cultural networks act as the infrastructure for social movements (Roberts and Moore 2009, 25), and the Bay Area has, for generations, exemplified these links between youth, music, protest and alternative life-styles: 'I don't give a damn what people say, I'm born and raised in the East Bay' (lyric, 'I ain't Worried'). Lyrically and visually, Rancid embrace this neighbourhood grounding through the setting for so many of their videos. This is especially evident in the video for 'Last One to Die', which celebrates the band's long-term survival. The video was shot in places around the East Bay of significance to Rancid's shared history, and with the band performing the song in Tim's sitting room. Their graphics also incorporate local landmarks, like the Golden Gate Bridge, and photos taken in the back streets of Albany.

As the band became less marginal themselves, as they began to tour more internationally and nationally, their political song-writing took on a more global flavour too. Outward looking, international, anti-war, their local grounding shapes their global perspective, with protest songs addressing settings as varied as Poland, Ireland, Yugoslavia, the Ivory Coast, China, Rwanda, Somalia, Central America, Iraq and Afghanistan. ${ }^{18}$ Perhaps their best-known song of this genre is 'Black Hawk Down', whose lyrics contain a lament that 'conflict in Somalia never came to an end, Strife in Sudan, ongoing contention, Battle in Sierra Leon, Hostilities in the Congo'.

\section{Summary and discussion of findings}

Taken together, the 12 paradoxical tensions presented here form the building blocks for Rancid's social construction of their punk rock entrepreneurship. The analytic structure, extensively illustrated with data, acts as a counterpoint, an alternative, a different lens, to contrast with, for example, Drakopoulou Dodd's 2002 model of US entrepreneurs' selfconception. This alternative form of entrepreneurship, with its highly context-specific expressions of power, place and practice, was built upon the early means at the band's disposal (see Figure 7). These means initially comprised the affective, cognitive, relational and productive resources of the East Bay Punx scene, which shaped Rancid's aesthetic and economic logics of cultural production through effectuation practices, and enabled them to take ever more control over their own future (Sarasvathy 2001, 250, 251, 2008). As Anderson, Drakopoulou Dodd, and Jack (2012) have recently argued, 'it is the 
connections to, and between, processes, people and places that become and explain entrepreneurship'. Starting from an idiosyncratic environment, and initially characterized by pronounced resource constraints - most especially in terms of economic capital Rancid nevertheless drew on a diverse range of embedded resources to create 'something out of nothing' enacting emergent bricolage (Baker and Nelson 2005, 356). Socially embedded resources included the ethos of DIY itself, approaches from friends and fellow punks with embryonic record labels (both Lookout! Records' Livermore and Epitaph's Gurewitz), Gilman as a venue for performance, the US independent punk tour circuit, ${ }^{19} \mathrm{MMR}$ and other zines, the accessible musical style of East Bay punk rock and their marginalized lives as a source of stories.

Place

Figure 7. Rancid's social construction of punk entrepreneurship.

Lounsbury and Glynn remind us that 'the content of entrepreneurial stories must align with audience interests and normative beliefs to enable favourable interpretations of a new venture' $(2001,550)$, and Rancid's personal tales from the underside continually ground them in the shared punk ethos. It is instructive that calls for greater consideration 
of multi-stream entrepreneurship have often been voiced in terms of exploring new contexts. Here, we find strong empirical support for the contextualization of entrepreneurship approach, in as much as social, geographic and cultural places are all of tremendous importance to Rancid and impact in very substantive ways upon their behaviours, norms and connections, as the analysis of their story has shown. ${ }^{20}$

As well as setting out and exploring a 'missing' organizing context for entrepreneurship, this study also makes a number of wider points. First, alternative organizing contexts to mainstream entrepreneurship can be deliberately constructed on the foundations of oppositional rhetorics and practices. Second, hybrid logics from the margins simultaneously amplify some 'traditional' aspects of entrepreneurship, whilst subverting others. Third, as a proposal for future research, paradox theory may offer a useful tool for us to think about entrepreneurship with.

The analytic frame deployed - place, power and practice - highlighted planes of Rancid's cultural code where differentiation was articulated. In some instances, this alterity took the form of sharply expressed divergence from the mainstream institutions of the (music) business, a combative rejection of its norms, processes and structures, and a firm commitment to resistance of its isomorphic pull. Yet in a handful of other cases such as Rancid's depictions of hard work, creativity and journeying - orthodox enterprise logics are invoked, and sometimes even amplified. Rancid's paradoxical cultural code allows for these contradictions to be perpetually held in conflicting tension. What we see, then, is a 'hybridization of...logics' (Jones and Thornton 2006a, 2006b, xiii), where a largely idiosyncratic and marginal logic nevertheless also draws on some elements of mainstream cultural codes in 'a form of institutional bricolage' (Maguire, Hardy, and Lawrence 2004, 674; see also Baker and Nelson 2005). Hybridization of cultural codes from institutional margins may be a particular form of cultural entrepreneurship engaged in by the peripheral.

Entrepreneurship scholarship has long engaged itself with those who are outside institutional borders, experiencing marginality and powerlessness due to their precarious socio-economic positions. Race, religion, indigeneity, gender, sexual orientation, rurality and informality have all been considered as socially marginalizing experiences which invoke quite specific forms of entrepreneurship. De Clercq and Voronov write of newcomer entrepreneurs,

those in less dominant positions are often ill-placed to experience and feel how they can turn around their current situation because they see the world through the lenses of the dominant and lack the necessary capital to bring about change. (2009a, 2009b)

Entrepreneurship from the disenfranchized margins, as we have already argued in Rancid's case, may make sense of itself in ways which draw upon the cultural codes of the mainstream in two ways. The first of these is though resisting, rejecting and opposing 
incumbent institutions, and choosing instead to build alternative meaning-frames and structures. Rancid's narrative of marginality, their discourse of protest and the alternative structures of production and consumption they have helped build illustrate this form of marginalized enterprise. Deliberately and carefully articulated rhetorics of opposition, as well as practices which enact this resistance, form an important element in the generation of (this example of) entrepreneurship at the margins. Powerlessness itself becomes a core resource that is deployed to resist the mainstream.

Second, there is evidence too of institutional bricolage being used to scavenge parts of mainstream cultural code for hybridization, whether deliberately, or through institutional diffusion. Scholars of the post-colonial have developed theories around hybridization of cultural code as a strategy for resisting the cultural frames of the dominant colonizer (Bhabha 1990, 1994; Frenkel 2008). Similarly, those beyond the margins of institutional power and economic capital in entrepreneurship - as this example from peripheral punk rock enterprise has shown - may be choosing independent innovative economic activity as a hybridized vehicle of resistance, survival and creativity. ${ }^{21}$ Marginal entrepreneurship, can be seen as a practice of subversion against dominant power-structures, which hybridizes the socio-cultural resources of in-between places with those of the centre.

The findings showed that, rather than a linear and consistent rhetoric of enterprise, Rancid's meaning frame was characterized by paradoxical tensions (Jay 2013; Lewis 2000; Smith and Lewis 2011). An important example is the discourse which depicts Rancid's entrepreneurial story as cycles, not just a linear journey, but as following more complicated paths - from periphery to centre, and back again; returning to roots, whilst trying to move forwards too; grounded in tradition but also radically focused on dramatic change of the status quo. Ambiguity and contradiction become paramount ways of engaging with the world, a key logic of organization, always in tension, always contested, never fixed. The findings raise the issue as to the potential value of paradoxical frames of entrepreneurship, much as Poole and Van de Ven (1999) proposed and, more recently, Smith and Lewis have articulated (2011) for management and organization theories. Jay (2013) shows that paradox may be of special significance to hybrid organizations. In resonance with what the Rancid case has shown us empirically, Smith and Lewis argue that their dynamic equilibrium theory of paradox can 'unleash human potential' since 'individuals can experience positive energy and success in response to the creativity and learning fueled from the juxtaposition of contradictory tensions' $(2011,394)$. Although outside the scope of the current discussion, the study's findings suggest that there may be usefully rich insights to be garnered by considering a paradox theory approach to entrepreneurship. 


\section{Conclusions}

The composition of a detailed social construction of entrepreneurship drawn from an unfamiliar context has ,I hope, been of merit on its own terms. Rancid's framing of punk rock entrepreneurship has illustrated the special importance, in some places, of noneconomic

capitals, andthepossibilityofcollective,creative, financiallysuccessfulentrepreneurshipthat nevertheless explicitly rejects privileging the individual pursuit of wealth and other corporate visions. The study has also embraced the inherent complexities of paradox and cycles of return, rather than more linear structured rational choice organizational logics.

The study has shown that marginal place, no matter how lacking in economic resources, can nevertheless act as a profoundly enabling habitus for 'missing' entrepreneurship. In this case, we have seen how it provides ethos (as in punk DIY, and the East Bay spirit of collective resistance), communities of strategic partners (as in Gilman, Rancid's early performance venue and rehearsal space; the Lookout! and Epitaph record labels; and the punk tour route) and the (trans-generational) social capital which confers legitimation and the stamp of authenticity within the outsider community, through the support of older musicians for their younger counterparts.

Powerlessness has thus been turned into a tool for resistance, which is expressed directly in discourse, and enacted through the building of alternative interlocking entrepreneurial structures. Continued avoidance of the mainstream's isomorphic pull facilitates long-lived autonomy. By staying largely outside the ambit of industry power structures - by remaining marginalized - freedom from mainstream dominance is achieved. Nevertheless, alternative norms (such as brotherhood, and the punk rock ethos) may act as self-imposed constraints upon this autonomy.

The practices identified in this study were found to be especially illustrative of the paradoxical nature of 'missing' entrepreneurship, often simultaneously combining an (amplified) mainstream practice, like journeying, with a marginal practice, like returning, to create rich, hybrid cultural codes.

All studies carry their own limitations, and this work is no exception. First, whilst we gain in focus by detailed examinations of single organizations, we may sacrifice opportunities for generalizability. Second, criticisms have also been levelled at scholars exploring punk rock with 'a level of engagement with punk that is more akin to casual tourism than active participation' (Furness 2012a, 2012b). This study did not emerge from years of immersion in a punk scene, but rather from formal qualitative analysis of punk artefacts. Whilst this is appropriate for exploration of the social constructions of enterprise communicated in these artefacts, nevertheless alternative ethnographic approaches, and direct interaction with the band, ${ }^{22}$ would have provided greater depth and richness to the study. It should also be acknowledged that even Rancid's sporadic and limited interactions with mainstream institutions have, for some punk rock 'purists', 
led to serious attacks on their authenticity as punks, and for these people, I am mistaken in continuing to refer to Rancid in this way. I can only quote Tim's answer:

am I a Punk Rocker? Absolutely, man. I tattoo'ed it on my knuckles, Lars tattoo'ed it on my knuckles. I don't give a fuck, I'm a punk rocker until I'm 100 years old, if I live that long.

(video footage of radio interview)

As is so often the case, the paper's limitations also suggest areas for future research. Ethnographic studies would add depth and further richness to this area, especially if longitudinal in nature. Rancid stay quite close to the borders of the margin, but there are much more oppositional forms of aesthetic and economic activity within punk. These are highly creative and independent agents and structures, founding (often collectively) grounded local ventures, and offer excellent examples of countercultural enterprise, very worthy of our attention (Thompson 2004).

In terms of implications for praxis, more diverse entrepreneurial narratives allow academics to present a wider range of role models, too. This is relevant for our classroom teaching, but also for those who engage with or advise on the margins, where grounded peripheral codes may be of special resonance. On the socio-economic margins, such models may allow us to speak to people - perhaps especially young people - of an entrepreneurship cut from their cloth.

Notes

1. This movement is mirrored within the multistream management research, also, 'to help escape the iron cage, or at least render it visible through contrast' (Dyck and Weber 2006, 430; see also Dyck and Schroeder 2005).

2. I am, like Johnstone and Lionais $(2004,218)$ following Hudson (2001) in contrasting 'space, which is an economic (capitalistic) evaluation of location based on its capacity for profit, with place, which is a social evaluation of location based on meaning'. There are other discussions of, and distinctions between, space and place in the philosophical and organization studies literature, perhaps most notably those drawing on the work of Lefebvre (1991) and de Certeau (1984); including Hernes (2004), Hjorth (2005), Beyes and Steyaert (2012), as a reviewer for this journal has kindly indicated. Further research could usefully deploy these understandings of space and place to detailed entrepreneurship studies, as exemplified by Hjorth's (2005) work.

3. 'Punk is an attempt to re-establish a sense of place, to create both a feeling of home and a spacefor contestation and self-expression' (Tucker 2012, 209). 'Punk then is not a moment but a territory, something that creates a space for other forms of being together and mapping out a space for bringing about another world in common' (Shukaitis 2012, 128).

4. Cultural constructions of entrepreneurship, as articulated in popular artefacts like music, havethe potential to offer important and novel insights, and may communicate these to wide sections of society. Rehn and Sko"Id $(2005,2007)$, for example, explore rap music as a minor economic literature.

5. Perhaps rather ironically, Salvation recounts Tim's experiences living and working in aSalvation Army hostel, during the very worst days of his alcoholism and drug abuse. 
6. Cultural sociologists Bennett and Petersen concur with this reading: 'In the establishedcorporate model, large firms produce, market, and distribute music, routinely referred to as "product", to an atomized mass of individual consumers' $(2004,4)$.

7. Although certainly not traditional source material, lyrics have in fact been analysed in similarstudies, most notably Rehn and Sko"Id's (2005), Sko"Id and Rehn (2008) series exploring rap music, as well as El-Sawad and Korczynski's (2007) splendid examination of the IBM song book (2007)..

8. A still more generous role was played at this stage by an editor and three anonymous referees, towhom I am also very grateful.

9. This image is repeated on other Rancid graphics, and ties them to the ethos of DIY which lanMacKaye's Minor Threat, Fugazi and Dischord Records represent in its purest form to the punk community (Thompson 2004, 42-43). English veteran punks GBH have since been signed to Hellcat, and have supported Rancid on some of their 20-year anniversary tour.

10. Thompson reports similar findings: 'The show takes precedence over all other forms of punk, because it combines music and community, and it an embodied phenomenon that can never be replicated or fully captured...many punk bands endeavour to create a representation of the energy of a live show' in their recordings (2004, 123; See also Miner and Torrez 2012, 44).

11. 'The reality of DIY encountered in this research is that of an uneven endeavour, and one whichhad its fair share of hardship and struggle factored into the task; although one should not forget that the fun and satisfaction...is of equal worth' (Gordon 2012, 107). Thompson $(2004,43)$ similarly quotes Dischord's lan Mackaye explaining that: 'you really have to do-ityourself - it's work'.

12. Arguments have been made that punk cycles, and nostalgia, can be seen as part of ongoinghistorical recurrences of socio-economic and cultural resistance (Thompson 2004, 133). Shukaitis, for example, argues that 'the kinds of social antagonism and rebellion that found their expression in anarchist punk were by no means new, but just one incarnation of the almost timeless desire to subvert social domination in all its forms and embody more cooperative ways of living and being in the world' (Shukaitis 2012, 129).

13. Thompson has argued that affect is in fact a key element in the construction and maintenance ofpunk authenticity: 'independent punk labels stand as the last bastion and protectors of affect, which punks read as proof of authenticity, in opposition to the major labour myopic attention to profit' $(2004,123)$.

14. Moore has reported similar findings in his study of DIY production also: 'Although musiciansmust pursue economic capital to some extent to subsist, their primary motivation is to accumulate symbolic capital by creating music whose quality and significance is recognized by a community of their peers' $(2007,453)$. Thompson argues along similar lines: 'punk producers and cultural products express a set of desires aimed at materially altering the mode of production...something other than the ability to survive off the money that they make from punk' $(2004,96)$.

15. Gurewitz, as well as owning and running Hellcat's parent label Epitaph, also produces most ofRancid's records. Indeed, they are reputed to be the only band, apart from his own Bad Religion, for whom Gurewitz still acts as a producer. 
16. The communitarian natureof DIY production and consumption have been notedby otherscholars,also: 'Methods of do-it-yourself cultural production not only intend to maximize creative control but also intent to enhance subcultural camaraderie, to make friends and support them...to find a sense of community with other musicians and cultural producers' (Moore 2007, 451).

17. The freedom to innovate and experiment is also perhaps best experienced from the periphery, asMoore argues: 'Independent record labels ... circulate cultural products that are typically more risky and experimental, products that generally are not attractive to a corporate culture industry that prefers to repeat successful or at least familiar formulas' (Moore 2007, 457).

18. 'To identify as punk is a maneuver to intentionally position one's self in solidarity withoppressed and colonized people, both locally and globally' (Miner and Torrez 2012, 31). Beyond this political stance, there are international punk networks, as set out in the DIY directory BYOFL (Book Your Own Fuckin' Life), of 'bands, distributors, record labels, record and book stores, radio stations, promoters, venues and zines ...restaurants, "crash pads"...print shops and websites' (Thompson 2004, 104; http://www.byofl.org/). Some writers ascribe this internationalization of punk 'trade routes' to the global scene reports carried in the East Bay zine MMR from its earliest issues (Thompson 2004, 116-117; quoting McNett 1986). This example highlights the longstanding context-derived nature of some of Rancid's cultural codes, with the East Bay scene long combining local grounding with international concerns.

19. LA band Black Flag is credited with having built the 'independent band national tour', as wellas founding one of California's first DIY record labels, SST.

20. Mainstreaming punk means that it will 'lose its oppositional nature and liberatory potential'(Miner and Torrez 2012, 32).

21. Similar conclusions have been reached by Georgiou et al. (2013) on the nature of entrepreneurial networking structures and practices among diverse marginalized and disempowered groups.

22. Rancid's drummer, Branden Steineckert, has very kindly read and provided supportivefeedback on a short summary of the paradoxes described here, which appeared as a blog post. He was generous in his appreciation of the basic model, its reading of Rancid and its implications. I am very grateful to him indeed for his time and care.

\section{References}

Alvesson, M., and K. Sko"Idberg. 2000. Reflexive Methodology: New Vistas for Qualitative Research. London: Sage Publications.

Anderson, A. R., S. D. Dodd, and S. Jack. 2010. "Network Practices and Entrepreneurial Growth." Scandinavian Journal of Management 26 (2): 121-133.

Anderson, A. R., S. Drakopoulou Dodd, and S. L. Jack. 2012. "Entrepreneurship as Connecting: Some Implications for Theorising and Practice." Management Decision 50 (5): 958-971.

Baker, T., and R. E. Nelson. 2005. "Creating Something from Nothing: Resource Construction Through Entrepreneurial Bricolage." Administrative Science Quarterly 50 (3): 329-366.

Banks, M. 2006. "Moral Economy and Cultural Work." Sociology 40 (3): 455-472.

Bennett, A., and R. Petersen. 2004. Music Scenes: Local, Translocal and Virtual. Nashville, TN: Vanderbilt University Press. 
Beyes, T., and C. Steyaert. 2012. "Spacing Organization: Non-Representational Theory and Performing Organizational Space." Organization 19 (1): 45-61.

Bhabha, Homi K., ed. 1990. Nation and Narration. London: Routledge.

Bhabha, Homi K. 1994. The Location of Culture. London: Routledge.

Bo"hm, A. 2004. "Theoretical Coding: Text Analysis in Grounded Theory." In A Companion to Qualitative Research. Translated by Bryan Jenner edited by U. Flick, E. von Kardorff, and I. Steinke, 270-275. London: Sage.

Bourdieu, P. 2000. Pascalian Meditations. Cambridge: Polity Press.

Bourdieu, P., and L. J. D. Wacquant. 1992. An Invitation to Reflexive Sociology. Chicago, IL: University of Chicago Press.

Ca'las,M.,L.Smircich,andK.Bourne.2009. "ExtendingtheBoundaries:Reframing'Entrepreneurship as Social Change' Through Feminist Perspectives." Academy of Management Review 34 (3): 552-569.

Certeau, M. D. D. E. 1984. The Practice of Everyday Life. Berkeley: University of California Press.

Chandler, G., and D. Lyon. 2001. "Issues of Research Design and Construct Measurement in Entrepreneurship Research: The Past Decade." Entrepreneurship Theory and Practice 25: 101-113.

Clemens, E. S., and J. M. Cook. 1999. "Institutionalism: Explaining Durability and Change." Annual Review of Sociology 25: 441-466.

Cope, J. 2005. "Researching Entrepreneurship Through Phenomenological Inquiry: Philosophical and Methodological Issues." International Small Business Journal 23 (2): 163-189.

Corley, K. G., and D. A. Gioia. 2004. "Identity Ambiguity and Change in the Wake of a Corporate Spin-Off." Administrative Science Quarterly 49: 173-208.

Coviello, N., and M. Jones. 2004. "Methodological Issues in International Entrepreneurship Research." Journal of Business Venturing 19 (4): 485-508.

Davidsson, P. 2013. "Some Reflection on Research 'Schools' and Geographies." Entrepreneurship and Regional Development 25 (1-2): 100-110.

De Clercq, D., and M. Voronov. 2009a. "The Role of Domination in Newcomers' Legitimation as Entrepreneurs." Organization 16 (6): 799-827.

De Clercq, D., and M. Voronov. 2009b. "Toward a Practice Perspective of Entrepreneurship Entrepreneurial Legitimacy as Habitus." International Small Business Journal 27 (4): 395419.

de Sa' Mello da Costa, A., and L. A. Luiz Alex Silva Saraiva. 2012. "Hegemonic Discourses on Entrepreneurship as an Ideological Mechanism for the Reproduction of Capital." Organization 19: 587-614.

Down, S. 2006. Narratives of Enterprise. Crafting Entrepreneurial Self-Identity in a Small Firm. Cheltenham: Edward Elgar.

Down, S. 2010. Enterprise, Entrepreneurship and Small Business. London: Sage.

Down, S. 2013. "The Distinctiveness of the European Tradition in Entrepreneurship Research." Entrepreneurship and Regional Development 25 (1-2): 1-4.

Drakopoulou Dodd, S. 2002. "Metaphors and Meaning: A Grounded Cultural Model of Us Entrepreneurship." Journal of Business Venturing 17 (5): 519-535. 
Drakopoulou Dodd, S., R. Smith, G. McElwee, and S. McDonald. Forthcoming. "Tales of Mystery and Imagination a Bourdieusian Analysis of Qualitative Authorship in Entrepreneurship Scholarship." Journal of Small Business Management.

Dyck, B., and D. Schroeder. 2005. "Management, Theology and Moral Points of View: Towards an Alternative to the Conventional Materialist-Individualist Ideal-Type of Management." Journal of Management Studies 42 (4): 705-735.

Dyck, B., and J. M. Weber. 2006. "Conventional Versus Radical Moral Agents: An Exploratory Empirical look at Weber's Moral-points-of-view and Virtues." Organization Studies 27 (3): 429-450.

Easterby-Smith, M., R. Thorpe, and A. Lowe. 1999. Management Research: An Introduction. London: Sage Publications.

El-Sawad, A., and M. Korczynski. 2007. "Management and Music: The Exceptional Case of the IBM Songbook." Group \& Organization Management 32 (1): 79-108.

Finch, J. 2002. "The Role of Grounded Theory in Developing Economic Theory." Journal of Economic Methodology 9 (2): 213-234.

Fletcher, D. E. 2011. "A Curiosity for Contexts: Entrepreneurship, Enactive Research and Autoethnography." Entrepreneurship and Regional Development 23 (1-2): 65-76.

Frenkel, M. 2008. "The Multinational Corporation as a Third Space: Rethinking International Management Discourse on Knowledge Transfer Through Homi Bhabha." Academy of Management Review 33 (4): 924-942.

Friedland, R. 2009. "The Endless Fields of Pierre Bourdieu." Organization 16 (6): 887-917.

Furness, Z. 2012a. "Attempted Education and Righteous Accusations: An Introduction of Punkademixs." In Punkademics; The Basement Show in the Ivory Tower, edited by Z. Furness, 5-24. Wivenhoe: Minor Compositions.

Furness, Z., ed. 2012b. Punkademics; The Basement Show in the Ivory Tower. Wivenhoe: Minor Compositions.

Gartner, W. B. 2004. "Achieving "Critical Mess" in Entrepreneurship Scholarship." In Advances in Entrepreneurship, Firm Emergence, and Growth, edited by J. A. Katz and D. Shepherd, 199216. Amsterdam: Elsevier.

Gartner, W. B. 2008. “Entrepreneurship - Hop.” Entrepreneurship Theory and Practice 32 (2): 361368.

Gartner, W. B. 2010a. "An Entrepreneurial Jeremiad." ENTER: Entrepreneurial Narrative Theory Ethnomethodology and Reflexivity 1 (1): 1-13.

Gartner, W. 2010b. "A New Path to the Waterfall: A Narrative on a Use of Entrepreneurial Narrative." International Small Business Journal 28 (1): 6-19.

Gartner, W. B. 2013. "Creating a Community of Difference in Entrepreneurship Scholarship." Entrepreneurship and Regional Development 25 (1-2): 5-15.

Garud, R., S. Jain, and A. Kumaraswamy. 2002. "Institutional Entrepreneurship in the Sponsorship of Common Technological Standards: The Case of Sun Microsystems and Java." Academy of Management Journal 45: 196-214.

Georgiou, C., S. Drakopoulou Dodd, C. Andriopoulos, and M. Gotsi. 2013. “Colonialism's Influence on National Patterns of Entrepreneurial Networking." International Small Business Journal. http://isb.sagepub.com/content/early/2011/06/29/0266242611404261.abstract

Glaser, B. G., and A. L. Strauss. 1967. The Discovery of Grounded Theory: Strategies for Qualitative Research. New York: Aldine. 
Golsorkhi, D., B. Leca, M. Lounsbury, and C. Ramirez. 2009. "Analysing, Accounting for and Unmasking Domination: On Our Role as Scholars of Practice, Practitioners of Social Science and Public Intellectuals." Organization 16 (6): 779-797.

Gordon, A. 2012. "Building Recording Studios Whilst Bradford Burned: DIY Punk Ethics in a Field of Force." In Punkademics; The Basement Show in the Ivory Tower, edited by Z. Furness, 104124. Wivenhoe: Minor Compositions.

Grant, P., and L. Perren. 2002. "Small Business and Entrepreneurial Research. Meta-Theories, Paradigms and Prejudices." International Small Business Journal 20 (2): 185-211.

Halinen, A., and J. A. Tornroos. 2005. "Using Case Study Methods in the Study of Contemporary Business Networks." Journal of Business Research 58 (9): 1285-1297.

Hargrave, T., and A. Van de Ven. 2006. "A Collective Action Model of Institutional Innovation." Academy of Management Review 31 (4): 864-888.

Hernes, T. 2004. Spatial Construction of Organization. Vol. 12. Amsterdam: John Benjamins.

Hjorth, D. 2005. "Organizational Entrepreneurship with de Certeau on Creating Heterotopias (or Spaces for Play)." Journal of Management Inquiry 14 (4): 386-398.

Hjorth, D., and C. Steyaert, eds. 2010. The Politics and Aesthetics of Entrepreneurship: A Fourth Movements in Entrepreneurship Book. Cheltenham: Edward Elgar.

Hudson, R. 2001. Producing Places. London: Guildford Press.

Imas, J. M., N. Wilson, and A. Weston. 2012. "Barefoot Entrepreneurs." Organization 19: 563-585. Jack, S. L., A. R. Anderson, S. Drakopoulou Dodd, and S. Moult. Forthcoming. "Using the Constant Comparative Technique to Consider Network Change and Evolution." In Handbook of Qualitative Research Techniques and Analysis in Entrepreneurship, edited by H. Neergaard, and C. Leitch. Cheltenham: Edward Elgar.

Johannisson, B. 2011. "Towards a Practice Theory of Entrepreneuring." Small Business Economics 36 (2): 135-150.

Johannisson, B., and L. Olaison. 2007. "The Moment of Truth - Reconstructing Entrepreneurship and Social Capital in the Eye of the Storm." Review of social Economy 65 (1): 55-78.

Johnstone, H., and D. Lionais. 2004. "Depleted Communities and Community Business Entrepreneurship: Revaluing Space Through Place." Entrepreneurship \& Regional Development 16 (3): 217-233.

Jones, C., N. Anand, and J. L. Alvarez. 2005. "Manufactured Authenticity and Creative Voice in Cultural Industries." Journal of Management Studies 42: 893-899.

Jones, C., and A. Spicer. 2005. "The Sublime Object of Entrepreneurship." Organization 12 (2): $223-$ 246.

Jones, C., and P. Thornton, eds. 2006. Transformation in Cultural Industries, Research in the Sociology of Organizations. Vol. 23. Amsterdam: Elsevier.

Jones, C., and P. Thornton. 2006. "Introduction." In Transformation in Cultural Industries, Research in the Sociology of Organizations, edited by C. Jones and P. Thornton. Vol. 23, xi-xxi. Amsterdam: Elsevier.

Jay, J. 2013. "Navigating Paradox as a Mechanism of Change and Innovation in Hybrid Organizations." Academy of Management Journal 56 (1): 137-159.

Lash, S., and J. Urry. 1994. Economies of Signs and Space. London: Sage.

Lefebvre, H. 1991. The Production of Space. Vol. 30. Oxford: Blackwell. 
Levy, D., and M. Scully. 2007. "The Institutional Entrepreneur as Modern Prince: The Strategic Face of Power in Contested Fields." Organization Studies 28 (7): 971-991.

Lewis, M. W. 2000. "Exploring Paradox: Toward a More Comprehensive Guide." Academy of Management Review 25 (4): 760-776.

Lounsbury, M., and M. A. Glynn. 2001. "Cultural Entrepreneurship: Stories, Legitimacy, and the Acquisition of Resources." Strategic Management Journal 22: 545-564.

Lounsbury, M., and M. Ventresca. 2003. "The New Structuralism in Organizational Theory." Organization 10 (3): 457-480.

Maguire, S., C. Hardy, and T. B. Lawrence. 2004. "Institutional Entrepreneurship in Emerging Fields: HIV/AIDS Treatment Advocacy in Canada." Academy of Management Journal 47 (5): 657679.

McRobbie, A. 2002. "From Holloway to Hollywood: Happiness at Work in the New Cultural Economy." In Cultural Economy, edited by P. du Gay and M. Pryke, 97-114. London: Sage.

Miner, D., and E. Torrez. 2012. "Turning Point, Claiming the University as a Punk Space." In Punkademics; The Basement Show in the Ivory Tower, edited by Z. Furness, 27-35. Wivenhoe: Minor Compositions.

Moore, R. 2004. "Postmodernism and Punk Subculture: Cultures of Authenticity and Deconstruction." The Communication Review 7: 305-327.

Moore, R. 2007. “Friends Don't Let Friends Listen to Corporate Rock: Punk as Field of Cultural Production." Journal of Contemporary Ethnography 36 (4): 438-474.

Moore, R. 2009. Sells like Teen Spirit; Music, Youth Culture, and Social Crisis. New York: New York University Press.

Negus, K. 1999. "The Music Business and Rap: Between the Street and the Executive Suite”. Cultural Studies 13 (3): 488-508.

Ogbor, J. 2000. "Mythicizing and Reification in Entrepreneurial Discourse: Ideology-Critique of Entrepreneurial Studies." Journal of Management Studies 37 (5): 605-635.

Peterson, R. 2005. "In Search of Authenticity." Journal of Management Studies 42 (5): 1083-1098.

Peterson, R. A. 2000. "Two Ways Culture is Produced." Poetics 28 (2): 225-233.

Petersen,R.,andA.Bennett.2004. "IntroducingMusicScenes."InMusicScenes:Local,Translocaland Virtual edited by A. Bennett, and R. Petersen, 1-15. Nashville: Vanderbilt University Press.

Poole, M., and A. Van de Ven. 1999. "Using Paradox to Build Management and Organization Theories." Academy of Management Review 14 (4): 562-578.

Rehn, A., and D. Sko"Id. 2005. "II Love The Dough': Rap Lyrics as a Minor Economic Literature.” Culture and Organization 11 (1): 17-31.

Rehn, A., and S. Taalas. 2004. "'Znakomstva I Svyazi'(Acquaintances and Connections)-Blat, the Soviet Union, and Mundane Entrepreneurship." Entrepreneurship \& Regional Development 16 (3): 235-250.

Roberts, M., and R. Moore. 2009. "Peace Punks and Punks Against Racism: Resource Mobilization and Frame Construction in the Punk Movement." Music and Arts in Action 2 (1): 21-36. Accessed May 24, 2011. http://musicandartsinaction.net/index.php/maia/article/view/ punkmovements

Sarasvathy, S. 2001. "Causation and Effectuation: Toward a Theoretical Shift from Economic Inevitability to Entrepreneurial Contingency." The Academy of Management Review 26 (2): 243-263.

Sarasvathy, S. 2008. Effectuation. Cheltenham: Edward Elgar. 
Shukaitis, S. 2012. "Growing up Cliche'd." In Punkademics; The Basement Show in the Ivory Tower, edited by Z. Furness, 126-129. Wivenhoe: Minor Compositions.

Silverman, D. 2000. Punkademics; The Basement Show in the Ivory Tower. Thousand Oaks, CA: Sage.

Sko"Id, D., and A. Rehn. 2007. "Makin' It, by Keeping It Real: Street Talk, Rap Music, and Forgotten Entrepreneurship From 'the 'Hood'." Group \& Organization Management 32 (1): 50-78.

Smith, W. K., and M. W. Lewis. 2011. "Toward a Theory of Paradox: A Dynamic Equilibrium Model of Organizing." Academy of Management Review 36 (2): 381-403.

Spencer, A. 2008. DIY: The Rise of Lo-Fi Culture. London: Marion Boyars.

Steyaert, C. 2005. "Entrepreneurship: In Between What?: On the 'Frontier' as a Discourse of Entrepreneurship Research." International Journal of Entrepreneurship and Small Business 2 (1): 2-16.

Steyaert, C. 2011. "Entrepreneurship as in (ter) Vention: Reconsidering the Conceptual Politics of Method in Entrepreneurship Studies." Entrepreneurship and Regional Development 23 (12): 77-88.

Steyaert, C., and D. Hjorth, eds. 2003. "New Movements in Entrepreneurship." Cheltenham: Edward Elgar.

Steyaert, C., D. Hjorth, and W. B. Gartner. 2011. "Six Memos for a Curious and Imaginative Future Scholarship in Entrepreneurship Studies." Entrepreneurship and Regional Development 23 (1-2): 1-7.

Steyaert, C., and J. Katz. 2004. "Reclaiming the Space of Entrepreneurship in Society: Geographical, Discursive and Social Dimensions." Entrepreneurship \& Regional Development 16 (3): 179196.

Steyaert, C., and H. Landstro"m. 2011. "Enacting Entrepreneurship Research in a Pioneering, Provocative and Participative Way: On the Work of Bengt Johannisson." Small Business Economics 36 (2): 123-134.

Svejenova, S., C. Mazza, and M. Planellas. 2007. "Cooking Up Change in Haute Cuisine: Ferran Adria as an Institutional Entrepreneur." Journal of Organizational Behavior 28: 539-561.

Tedmanson, D., K. Verduyn, C. Essers, and W. B. Gartner. 2012. "Critical Perspectives in Entrepreneurship Research Organization." 19: 531-541.

Thompson, S. 2004. Punk Productions: Unfinished Business. New York: State University of New York Press.

Tucker, B. 2012. "Punk Places: The Role of Space in Subcultural Life." In Punkademics; The Basement Show in the Ivory Tower, edited by Z. Furness, 203-215. Wivenhoe: Minor Compositions, Creative Economy Report 2008, UNCTAD.

Watson, T. J. 2013. "Entrepreneurial Action and the Euro-American Social Science Tradition: Pragmatism, Realism and Looking Beyond 'The Entrepreneur'." Entrepreneurship and Regional Development 25 (1-2): 6-33.

Welter, F. 2011. "Contextualizing Entrepreneurship - Conceptual Challenges and Ways Forward." Entrepreneurship Theory and Practice 35 (1): 165-184. 


\section{Appendix 1. Twenty examples of directly relevant journalist questions in the data-set}

Nik Harcourt 'Let's talk about Hellcat, which is actually a sublabel of Epitaph, which is Brett's label. Started in 1997. First of all, why did you start your own label?'

Nik Harcourt 'If you look at where we are today, as a label guy, what's the best way to get the music out there today?'

Nik Harcourt 'Are sales still relevant to an artist, or is it about getting the message out through as many means as possible, to as many people as possible, just to get fans out to shows?'

Nik Harcourt 'How important is social media'

Nik Harcourt 'What does having a signature guitar mean to you' Decider:

How do you think Rancid has managed to stick it out for so long?

Decider: At this point, is friendship more important than making music?

Decider: Rancid is still rooted in working-class concerns, despite punk's ascent into middle-class suburbia. How important is it to keep your blue-collar grounding?

Decider: You played with The Ramones at their last show and Tim put out Joe Strummer's last three albums. How much of an impact was it having direct contact with those legends?

Decider: Is that part of the inspiration for you to run your own label, Hellcat Records?

Gabriella: It's truly unusual for a band to stick with an indie label when they are courted by basically every major record company...

Punkrockacademy: A lot of the songs on this album seem to deal with more personal topics. Rancid has always dealt with political issues through personal stories, but on this album, how did you go about doing that?

Punkrockacademy: I was talking to a friend about the Clash once, and I said the Clash were about soul survival, and it seems like Rancid is as well. Would you agree with that?

Punkrockacademy: Another thing I liked about the album were the references and places, like calling a song 'Olympia', and the places that were written about, like Cleveland in 'Old Friend'. This album seems to be all over the map, literally.

R13: It's become a bit of a tradition for members of Rancid to start their own side projects. Why has it been so important for you guys to explore other things in this way?

Shockhound: This is easily your angriest album yet. What do you see happening out there in the world?

Shockhound: Nothing against Green Day for graduating to arena superstardom. But why not Rancid? You guys have songs that are just as memorable.

Hit Parader: How surprised have you been by Rancid's success?

Hit Parader: So many people seem to view Rancid along with Green Day's some sort of contrived punk unit conceived just to sell millions of records.

HIT Parader: Some people might think that the reports of you living on the street just a few years ago are just part of a good story. Is it really true?

Skratch: Politics definitely makes an appearance on your albums. Do you think your lyrics are politically powerful enough to teach your listeners the concerns they should look after? 
Appendix 2. Listings of primary data sources

\begin{tabular}{lcccc}
\hline \multicolumn{5}{c}{ Rancid's Studio albums } \\
\hline Title & Date & Word count & Units & $\begin{array}{c}\text { Data } \\
\text { count }\end{array}$ \\
\hline Rancid & 1993 & & 15 songs & 112 \\
Let's go & 1994 & & 23 songs & 100 \\
And out come the wolves & 1995 & 3226 & 19 songs & 83 \\
Life won't wait & 1998 & 6428 & 22 songs & 136 \\
Rancid 2000 & 2000 & & 22 songs & 46 \\
Indestructible & 2003 & 5412 & 19 songs & 115 \\
Let the dominoes fall & 2009 & 3363 & 19 songs & 72 \\
Artwork & $93-09$ & & 7 albums & 36 \\
& & & 117 songs & 700 \\
\hline
\end{tabular}

Text reviews and interviews

Livermore, L (2009) Journey To The End: Tim Armstrong, Matt Freeman and Lars Frederiksen talk to Larry Livermore about Operation Ivy, Rancid and that whole East Bay thing. http://larryl ivermore.com/?p⿳亠丷厂彡323. Posted 27 August 2009, interview conducted in 2001. Retrieved 10 March 2011 12:01 PM

Amberleigh Jack (2009) http://www.therock.net.nz/Rancid-interview/tabid/673/articlelD/5797/ Default.aspx. Accessed 10th March 2011 16:23

Shield, Matt, 25 June 2009 Tim Armstrong and Lars Frederiksen of Rancid. http://www.avclub.com/ twincities/articles/tim-armstrong-and-lars-frederiksen-of-rancid,29128/. Accessed 10th March 2011

$16: 16$

http://www.punkrockacademy.com/stm/int/rancid.html. Accessed 10th March 2011 16:09 (Interview with Matt) http://rancidfans.livejournal.com/78011.html, Tim Armstrong Primer and Picspam, Valerie Z2009. Accessed 27 May 2011

http://www.nyrock.com/interviews/rancid_int.htm, Gabriella, October 1998

Sleigh, R (2010) Interview with Rancid's Matt Freeman. http://www.roomthirteen.com/cgibin/ feature_view.cgi?FeatureID1/4790. Accessed 10th March 2011 16:00

MaximumRockNRoll 1 (July 1982) http://www.operationphoenixrecords.com/Maximumrocknroll/ MRR-Issue001-1-IntroandLetters.pdf, Friday 27 May 2011

MaximumRockNRoll 42 (November 1986) http://www.operationphoenixrecords.com/Maximu mrocknroll/MRR-Issue042-16-924GilmanSt.pdf, Friday 27 May 2011 
MaximumRockNRoll 57 (January 1988) http://www.operationphoenixrecords.com/Maximu mrocknroll/MRR-Issue057-8-Operationlvy.pdf, Friday 27 May 2011

Brown, A (2009) http://latimesblogs.latimes.com/music_blog/2009/06/rancids-let-thedominoesfall-feels-like-a-punkhomecoming.html. Posted 3 June 2009 j 6:28 pm. Accessed 10th March 2011 4:47 PM

Lanham, T (2009) 'Rancid: Hope And Glory, Interview'. http://community.hottopic.com/interview/ rancid-hope-andglory. Accessed 10th March 2011 4:54 PM

Spoiled Rotten, Interview with Tim Armstrong. http://www.oocities.org/vivo_80/TimArmstrong1. Accessed 10th March 2011

Annette Ovanessian, Thursday 9 September 2004, Interview with Lars Frederiksen from Skratch Magazine. LARS FREDERIKSEN \& THE BASTARDS. http://www.epitaph.com/news/news/1627.

Accessed 10th March 2011

Janelle Jones THE OLD FIRM CASUALS posted by By alina on 11 April 2011. http://www.amp magazine.com/11765/theold-firm-casuals-interview-with-lars-fredericksen/. Accessed 4th May 2011

Epitaph's Rancid Band Description. http://www.epitaph.com/artists/artist/61/Rancid\#albdesc. Accessed 16th March 2011

Video interviews and documentaries http://www.youtube.com/watch?NR1/41\&v 1/4 gSmyo2uhdc\&. MTV Europe Interview mid-90s. Last accessed Monday 11 June 2012 2:46min

http://www.youtube.com/watch?v/4Ry3K8ReHEhg\&feature 1/4 related. Behind the ink. 2012 Lars Frederiksen 19.20min 6 November 2012 9:08 AM

http://www.youtube.com/watch?v1/4753bpgYmOT4\&NR 1/4 1. Lars talks to Eric Blair, 2005. Last accessed 27 May 2011 6.30min

http://www.youtube.com/watch?v¹/4AfOvdeTXD5M. Brian gets tattoed by Lars. Accessed 5 April

2011 12:46 PM 9.55min

http://www.youtube.com/watch?v1/4Jb_v4EeTpho\&NR 1/4 1. Lars tattooing Jeff Cardell, at NYHC

1. Accessed 5 April 2011 12:56 PM 0.44min

http://www.youtube.com/watch?v¹/4s8DGHN25w9s\&feature 1/4 related. Lars tattooing Jeff Cardell, at NYHC 2. Accessed 5 April 2011 12:56 PM 0/48min

http://www.youtube.com/watch?v/4|OibahtB5Bc\&feature 1/4 related. 2010 Interview, for onenineninefour, with Tim about the breakup of Op Ivy 5 April 2011. Accessed 5 April 2011 1.26min http://www.youtube.com/watch?v/4dEiD4nzyXdM. Rancid TV interview, 2006 'we're all brothers'. Accessed 09 May 2011 1.23min

http://www.youtube.com/watch?v¹/4169vFeq_4p4. DJ Hikaru Interview in Japan, 6 March 2006 Rancid Radio, Residency, and Tours, showcasing young bands. Accessed 09 May 2011 3.11min http://www.youtube.com/watch?v1/4m2LOXXU3y8U. Joe Strummer Tribute (making of). Last accessed 27 May 2011 1.01min

http://www.youtube.com/watch?v/4cBjQPjivRiQ\&feature 1/4 related. Interview with Tim, 'Who's a Punk - I'm not a cop' 6 November 2012 9:07 AM 1.17min 
http://www.youtube.com/watch?v¹/4zJqIVUOPkwY\&list1/4PL59FC3B983474FB8B\&index $\quad 1 / 4 \quad 9 \&$ feature $1 / 4$ plpp_video. Interview with Rancid, Japan 2003, Warped Tour 6 November 2012 9:14 AM $1.48 \mathrm{~min}$

http://www.youtube.com/watch?v1/4500fllFEATs\&feature $\quad 1 / 4$ BFa\&list $\quad 1 / 4 \quad$ PL59FC3B983474FB8B \&index¹/414. Rancid interview, Japanese interview 20046 November 2012 9:47 AM 4.44min http://www.youtube.com/watch?v1/4tClkO2ieLT8\&feature1/4BFa\&list 1/4 PL59FC3B983474FB8B. Lars interview (Rancid 2000) 6 November 2012 9:47 AM 3.28min

http://www.youtube.com/watch?v1/4LuesBCviK5U\&feature1/4related. Nardwuar interview, 2003

(Indestructible) 6 November 2012 9:59 AM 4.57min

http://www.youtube.com/watch?v1/4zMOFhWvCFt8\&feature1/4related. Hikaru interview, Tim's house 2003 (Indestructible) 6 November 2012 10:09 AM 13:56min

\section{Music videos}

http://www.youtube.com/watch?v¹/43AEw1c2dt1g. Rancid / Hellcat Records, 'Red Hot Moon' video, Circulated 2003. Last accessed 27 May 2011

http://www.youtube.com/watch?v¹/4wOS2205KLXg. 'Another East Bay Night' - Live Acoustic Version, Circulated 2009. Last accessed $27 \quad$ May 2011 http://www.youtube.com/watch?v1/4wrKwymyErf8\&feature1/4artist. Rancid/Hellcat Records, 'Last One to Die' video, Circulated 2009. Last accessed 27 May 2011

http://www.youtube.com/watch?v//4ilsd2ajX6qk\&feature1/4artist. Rancid/Hellcat Records, 'Up to No Good' video, Circulated 2009. Last accessed 27 May 2011

http://www.youtube.com/watch?v1/4lwlbb3McVW4\&feature1/4artist Rancid/Epitaph Records,

'Time Bomb' video, Circulated 1995. Last accessed 27 May 2011

http://www.youtube.com/watch?v//4fEBcEdFqaeE\&. Rancid - ‘Olympia WA' (BLAST Surf N Skate 2010). Last accessed 27 May 2011

http://www.youtube.com/watch?v1/4-jK6uDrDe1Q\&feature1/4related. Rancid - 'The 11th Hour'

(BLAST Surf N Skate 2010). Last accessed 27 May 2011

http://www.youtube.com/watch?v¹/48VTzrzU38cY. Hyena. Last accessed 13 June 2012 14:39 http://www.youtube.com/watch?v/4qFNfMwdHezO. Blood clot. Last accessed 13 June 2012 14:39 http://www.youtube.com/watch?v¹/42WOx4U3sCuQv. Nihilism. Last accessed 13 June 2012 14:39 http://rancidrancid.com/videos/2012/01/13/crane-fist/. Crane Fist. Last accessed 13 June 2012 14:39 http://rancidrancid.com/videos/2012/01/13/poison/. Poison. Last accessed 13 June 2012 15:07 http://rancidrancid.com/videos/2012/01/13/rattlesnake/. Rattlesnake video. Last accessed 13 June 2012 15:07

http://rancidrancid.com/videos/2012/01/13/spirit-of-87/. Spirit of87. Lastaccessed13 June 2012 15:07 http://www.youtube.com/watch?feature1/4player_embedded\&v 1/406DwC3xbl1Q. Black Derby Jacket. Last accessed June 2012 15:40

http://rancidrancid.com/videos/2012/01/13/rwanda/. Rwanda. Last accessed 13 June 2012 15:31 http://rancidrancid.com/videos/2012/01/13/blackhawk-down/. Blackhawk Down 13 June 2012 16:09 
http://rancidrancid.com/videos/2012/01/13/hooligans/. Hooligans 13 June 2012 4:21 PM http://rancidrancid.com/videos/2012/01/12/live-in-the-living-room-wrongful-suspicion/. Live in the living room, wrongful suspicion 13 June 2012 16:24

http://rancidrancid.com/videos/2012/03/15/20-years-of-rancid-2/. 20 years of Rancid. Last accessed 13 June 2012 14:39

http://rancidrancid.com/videos/2012/01/11/salvation/. Salvation. Last accessed 13 June 2012

16:49 http://www.youtube.com/watch?v1/4Z3_eER2-6S8. Let me go. Last accessed 13 June 2012 16:49 http://www.youtube.com/watch?v1/4ilsd2ajX6qk. Up to no good. Last accessed 13 June 2012 16:49 http://www.youtube.com/watch?v/4uYW3mVUyUtl. Last One to Die. Last accessed 13 June 2012 17:06

http://www.youtube.com/watch?v1/4mvfgWNOaNa8. Fall Back Down. Last accessed 13 June 2012

17:06

http://rancidrancid.com/videos/2012/01/12/live-in-the-living-room-tenderloin/. Living Room Tenderloin. Last accessed 13 June 2012 17:28

http://rancidrancid.com/videos/2012/01/12/live-in-the-living-room-shes-automatic/. Living Room She's Automatic. Last accessed 13 June 2012 17:28

http://rancidrancid.com/videos/2012/01/12/live-in-the-living-room-4/. Living Room 4 - On a night like this. Last accessed 13 June 2012 17:28

http://rancidrancid.com/videos/2012/01/11/i-am-forever/. I am forever. Last accessed 13 June 2012

$17: 28$

http://www.youtube.com/watch?feature 1/4player_embedded\&v1/49nl65aC1Ukk with Dropkick

Murphies Skinhead on the MTBA. Last accessed 13 June 2012 17:40

'Let the Dominoes Fall' Webisodes

http://www.youtube.com/watch?v1/4elOrg5RNqeU\&feature1/4player_embedded\#at1/424. 'Let the Dominoes Fall', Rachel Tejade, Webisode 1, Uploaded by Hellcat records, 27 April 2009. Last accessed 27 May 2011

http://www.youtube.com/watch?v/4ZA4h5mMWiXk\&feature1/4 related. 'Let the Dominoes Fall', Rachel Tejade, Webisode 2, Uploaded by Hellcat records, 27 April 2009. Last accessed 27 May 2011 http://www.youtube.com/watch?v1/4kUJ8AM2vZOs\&feature1/4 relmfu. 'Let the Dominoes Fall', Rachel Tejade, Webisode 3, Uploaded by Hellcat records, 27 April 2009. Last accessed 27 May 2011 http://www.youtube.com/watch?v1/4GV8ncKoDg2c\&feature $1 / 4$ relmfu. 'Let the Dominoes Fall', Rachel Tejade, Webisode 4, Uploaded by Hellcat records, 27 April 2009. Last accessed 27 May 2011 http://www.youtube.com/watch?v1/4Df6bCzmAgXE\&feature 1/4 relmfu. 'Let the Dominoes Fall', Rachel Tejade, Webisode 5, Uploaded by Hellcat records, 29 April 2009. Last accessed 27 May 2011 http://www.youtube.com/watch?v1/4tVvmug8wVp4\&NR1/4 1. 'Let the Dominoes Fall', Rachel Tejade, Webisode 6, Uploaded by Hellcat records, 30 April 2009. Last accessed 27 May 2011 http://www.youtube.com/watch?v1/4|xHpQgVxelQ\&feature $1 / 4$ relmfu. 'Let the Dominoes Fall', Rachel Tejade, Webisode 7, Uploaded by Hellcat records, 1 May 2009. Last accessed 27 May 2011 http://www.youtube.com/watch?v1/4DGQLXCxvocM\&feature1/4 relmfu. 'Let the Dominoes Fall', Rachel Tejade, Webisode 8, Uploaded by Hellcat records, 4 May 2009. Last accessed 27 May 2011 http://www.youtube.com/watch?v1/4QqS2rgC07os\&feature $1 / 4$ relmfu. 'Let the Dominoes Fall', 
Rachel Tejade, Webisode 9, Uploaded by Hellcat records, 5 May 2009. Last accessed 27 May 2011 http://www.youtube.com/watch?v1/41-hmvz2cE1Y\&feature $1 / 4$ relmfu. 'Let the Dominoes Fall', Rachel Tejade, Webisode 10, Uploaded by Hellcat records, 6 May 2009 Webisode 10 http://www.youtube.com/watch?v1/4nf4jeB_vk-o\&feature $1 / 4$ related. 'Let the Dominoes Fall', Rachel Tejade, Webisode 11, Uploaded by Hellcat records, 7 May 2009

http://www.youtube.com/watch?v1/4y0EWyDiFW18\&NR11/4 1. 'Let the Dominoes Fall', Rachel Tejade, Webisode 12, Uploaded by Hellcat records, 8 May 2009

http://www.youtube.com/watch?v1/4KmC8ggREDEY\&feature1/4relmfu. 'Let the Dominoes Fall', Rachel Tejade, Webisode 13, Uploaded by Hellcat records, 11 May 2009

http://www.youtube.com/watch?v1/4p91eHKPxVsk\&feature1/4relmfu. 'Let the Dominoes Fall', Rachel Tejade, Webisode 14, Uploaded by Hellcat records, 12 May 2009

http://www.youtube.com/watch?v1/4n6nW7xhDgw\&feature $1 / 4$ relmfu. 'Let the Dominoes Fall', Rachel Tejade, Webisode 15, Uploaded by Hellcat records, 13 May 2009

http://www.youtube.com/watch?v1/46-3INRunr4Y\&feature1/4relmfu. 'Let the Dominoes Fall', Rachel Tejade, Webisode 16, Uploaded by Hellcat records, 14 May 2009

http://www.youtube.com/watch?v1/43cH2UPjthMw\&feature1/4relmfu. 'Let the Dominoes Fall', Rachel Tejade, Webisode 17, Uploaded by Hellcat records, 18 May 2009

http://www.youtube.com/watch?v1/4cOhrrbUAb3I\&feature1/4relmfu. 'Let the Dominoes Fall', Rachel Tejade, Webisode 18, Uploaded by Hellcat records, 18 May 2009

http://www.youtube.com/watch?v1/4pBgevPPwXKw\&feature1/4relmfu. 'Let the Dominoes Fall', Rachel Tejade, Webisode 19, Uploaded by Hellcat records, 19 May 2009

http://www.youtube.com/watch?v1/4uCRgKVfEFH8\&feature $1 / 4$ relmfu. 'Let the Dominoes Fall', Rachel Tejade, Webisode 20, Uploaded by Hellcat records, 20 May 2009

Other web-based sources

http://gc.guitarcenter.com/podcast/\#tim. Guitar centre podcast interview with Tim, hosted by Nik Harcourt, March 2012. Last accessed 14 June 2012 10:16 58min 69 data

http://www.doganddeuce.com/2012/04/02/dd-67-branden-steineckert-interview/. 2 April 2012

Radio interview with Brandon 48min. Last accessed 14 June 2012 16:22

Facebook posts (reviewed 153 posts, from December 232011 to June 14 2012)

Twitter - Largely mirrors Facebook. Reviewed 250 Tweets and Retweets (30th January 2012 - 14th June 2012)

http://rocknrolltheater.tv/. RockNRoll Theatre Song, from Dante 'We did Alright', Trailer. Last accessed 14 June 2012

http://machetemfg.com/. Machete Manufacturing Website. Review of listed bands, Email correspondence. Last accessed 14 June 2012 17:31

http://www.hell-cat.com/. Hellcat Records Website. Last accessed 14 June 2012 17:31

http://unknownstudios.net/. Branden Steineckert's Unknown Studios Website. Last accessed 14 June 2012 17:31

http://undercovers.bigcartel.com/https://www.facebook.com/HideUnderCovers. Branden Steineckert's Undercovers venture. Last accessed 14 June 2012 17:31

Branden Steineckert's facebook page and Twitter account. Last accessed 14 June 2012 17:31 